\title{
Jurassic evolution and the structure of the central part of the Pieniny Klippen Belt (Carpathians) in Poland - new insight from the Czertezik Succession type area
}

\author{
Andrzej WIERZBOWSKI ${ }^{1}$, Hubert WIERZBOWSKI ${ }^{2}$, Tomasz SEGIT $^{1}$, Michał KROBICKI ${ }^{3}$
}

Key words: Toarcian-Aalenian-lowermost Bajocian reworked deposits, rifting phases, Czertezik Ridge.

\begin{abstract}
The Czertezik Succession of the Pieniny Klippen Belt in Poland is assigned herein to its type area of occurrence - the main Pieniny Range, between Zamkowa Góra and Czertezik mounts. The reworked deposits of uppermost Pliensbachian, Toarcian and possibly Aalenian to lowermost Bajocian discovered in crinoidal limestones which indicate redeposition processes, especially during the Bajocian, are considered to be clearly important for reconstructing the depositional history. The redeposited Pliensbachian is represented by clasts of spotty limestones, the Toarcian by ferruginous grains and fragments of crusts/large oncoids of the ammonitico-rosso type (?Adnet Fm.), whereas the Aalenian and lowermost Bajocian is possibly represented by clasts of siliciclastic deposits and phosphatic nodules. This part of the succession resulted from the activity of rifting phases at the end of the Early Jurassic, and in the Bajocian, which caused the development of the special sedimentary environments typical of the Czertezik Succession. The younger Middle to Late Jurassic deposits represented by nodular limestones, radiolarites and micritic well-bedded limestones show a less distinct facies pattern, which is in part similar to that of other successions of the Pieniny Klippen Belt, although some rock-units such as the newly established Zamkowa Góra Bed, revealing the continuation of redeposition processes, remain specific to the Czertezik Succession. The Jurassic structure of the central part of the Pieniny Klippen Belt in Poland is revised due to the introduction of the Czertezik Ridge as a new palaeogeographic unit being the place of deposition of the Czertezik Succession. The revised position of the deposits shifts the structural affinity of the Czertezik Succession from the Subpieniny Nappe to the base of the Pieniny Nappe sensu Uhlig, 1907, and implies its closer palaeogeographic position to the Branisko-Pieniny successions than to the Czorsztyn-Niedzica successions as has been interpreted so far.
\end{abstract}

\section{INTRODUCTION}

The sedimentary basins of the Pieniny Klippen Belt (Fig. 1) include several facies zones, but their detailed palaeogeographic pattern during the Jurassic has remained the subject of various interpretations. It is because of the extremely complicated tectonic structure of this mountain range placed in between the Outer and Central Western
Carpathians and corresponding to an active oceanic/continental margin setting which resulted in several deformation phases in the Mesozoic and the Caenozoic, during the Alpine orogeny. The Pieniny Klippen Belt is bounded to the south, along of its whole length, by a large boundary fault of Miocene age, whereas its northern boundary is rather discrete and passes through a transition zone into the Magura Nappe of the Outer Carpathians (Jurewicz, 2018; Jurewicz,

\footnotetext{
${ }^{1}$ Faculty of Geology, University of Warsaw, Żwirki i Wigury 93, 02-089 Warszawa, Poland; andrzej.wierzbowski@uw.edu.pl, t.segit@uw.edu.pl.

${ }^{2}$ Polish Geological Institute - National Research Institute, Rakowiecka 4, 00-975 Warszawa, Poland; hubert.wierzbowski@pgi.gov.pl.

${ }^{3}$ AGH University of Science and Technology, Faculty of Geology, Geophysics and Environmental Protection, Mickiewicza 30, 30-059 Kraków, Poland; krobicki@geol.agh.edu.pl.
} 


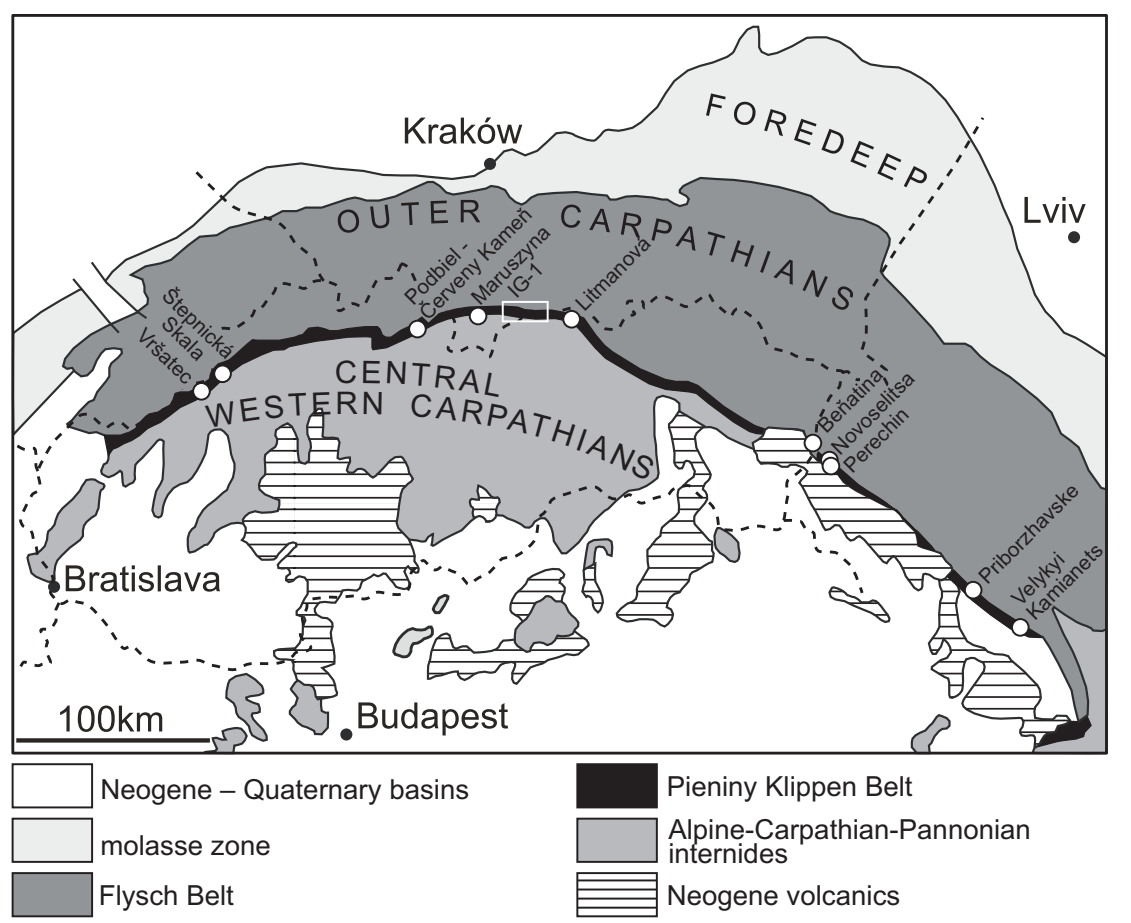

Fig. 1. Location map of the Pieniny Klippen Belt showing the position of the main sections in Poland, Slovakia and Ukraine and the area of the study (in rectangle)

Segit, 2018). Additionally, in relation to the transverse faults, the whole belt has been subdivided into large segments which reveal somewhat different structural settings of the Jurassic-Cretaceous units due to vertical and/or lateral displacements (e.g., Birkenmajer, 1986, 2017).

The tectonic structure of the Pieniny Klippen Belt sensu stricto (i.e. without the so-called Peri-Klippen Zone sensu Plašienka, 2019) is composed of three megatectonic units: the Subpieniny Nappe and the overlying Pieniny Nappe distinguished already by Uhlig (1907) which constitute the main elevated parts of the mountain range, and the underlying Šariš Unit (see Plašienka, 2012, and earlier papers cited therein), interpreted also as belonging to the Magura Nappe (Šariš Transitional Zone sensu Jurewicz, 2018). The two former units correspond to several facies-tectonic JurassicCretaceous successions in the Pieniny Klippen Belt in Poland such as the Czorsztyn Succession, the Niedzica Succession, the Czertezik Succession, the Branisko Succession, and the Pieniny Succession (e.g. Birkenmajer, 1977, 1986, 1988 with some modification - Krobicki, Wierzbowski, 2004; Wierzbowski et al., 2004), whereas the Šariš Unit (Plašienka, Mikuš, 2010) correlates with the Grajcarek Succession (or the earlier Magura Succession as distinguished here, see Birkenmajer, 1977, 1986). The latter is the lowermost tectonic unit, which appears below the overthrusted deposits of the Czorsztyn to Branisko successions in several areas of the Pieniny Klippen Belt in Poland (Barski et al., 2012; Segit et al., 2015).

The Czertezik Succession was recognized by Birkenmajer (1959) as the last one of the palaeogeographic (and tectonic) units distinguished by him and called the "klippen series" (later "successions") in the Jurassic and Cretaceous of the Pieniny Klippen Belt in Poland. From the very beginning up to recent times however, its palaeogeographic position, details of the sedimentary column, as well as the regional distribution of the deposits has become the subject of various interpretations (e.g., Birkenmajer, 1977, 2007, 2017; Wierzbowski et al., 2004; Krobicki, Wierzbowski, 2009). Because of differences in the lithological logs of deposits attributed to the Czertezik Succession in various parts of the Pieniny Klippen Belt, the interpretation of this succession as given herein is limited to the area recognized originally (Birkenmajer, 1959) as the most characteristic (locus typicus) of its occurrence - the main Pieniny Range. It stretches from Zamkowa Góra and Wielka Pustelnica mounts in the west, through the Pieniński Creek gorge, and to the Czerwone Skałki and Czertezik mounts in the east, generally in a poorly accessible area of the central part of the Pieniny National Park in Poland, close to the Dunajec River valley gorge, near the boundary with the Slovak Republic. Deposits of the Czertezik Sucession occur at the northern fringe of the area of occurrence of the Pieniny Succession, accord- 
ing to Birkenmajer $(2007,2017)$, appearing in the tectonicwindow (Czertezik - Zamkowa Góra Tectonic Window or Pieniński Potok Tectonic Window) from below the overthrusted deposits of the Branisko (southern type as recognized herein) - Pieniny Nappe. The detailed description of the Jurassic deposits of the Czertezik Succession cropping out in this area is based on more recent advances, especially in relation to the stratigraphical interval of the uppermost Lower and lowermost Middle Jurassic, which have only been partly studied (Wierzbowski et al., 2009; Krobicki, Wierzbowski, 2009; Wierzbowski et al., 2019). The sedimentary columns of deposits attributed so far to the Czertezik Succession in other areas of the Pieniny Klippen Belt in Poland, and the existing differences and similarities when compared with the typical development of the Czertezik Succession of the main Pieniny Range, are discussed also below.

The interpretation of the palaeogeographic position of the Czertezik Succession has an important implication for recognition of the history and the geological structure of the Pieniny Klippen Belt. The main subject of this study becomes thus the Jurassic part of the Czertezik Succession in the Pieniny Klippen basins, and the related dilemma of its structural and palaeogeographic location either at the edge of the well-known Czorsztyn Ridge in the north (as interpreted e.g. by Birkenmajer, 1977, 2017) and of the Czorsztyn-Niedzica successions, corresponding to the Subpieniny Nappe, or more towards the south and in close relation to the Branisko-Pieniny successions, i.e. to the Pieniny Nappe as suggested herein.

\section{MATERIAL AND METHODS}

The boundary beds of the Lower Jurassic spotty limestones and marls of the Szopka Limestone Formation and the Middle Jurassic crinoidal limestones of the Smolegowa Limestone Formation at Wielka Pustelnica Mt. were precisely sampled in years 2018-2019. A total of 21 thin sections were prepared and investigated for textural and petrographical features using a polarizing light microscope (Zeiss Axio Scope.A1). Selected thin sections were studied at the Micro-area Analysis Laboratory of the Polish Geological Institute - National Research Institute in Warsaw using a CAMECA SX 100 electron microprobe. The studies included energy dispersive spectrometry (EDS) analyses of concentration of 19 chemical elements $(\mathrm{Na}, \mathrm{F}, \mathrm{Si}, \mathrm{Al}, \mathrm{Mg}$, $\mathrm{Ca}, \mathrm{K}, \mathrm{Cl}, \mathrm{Cu}, \mathrm{Ni}, \mathrm{Fe}, \mathrm{Mn}, \mathrm{Cr}, \mathrm{V}, \mathrm{Ti}, \mathrm{S}, \mathrm{P}, \mathrm{Sr}, \mathrm{Pb}$ ) in noncarbonate and non-quartz phases of the thin sections and back scattered electron (BSE) analysis of the density of mineral phases. The detection limits $(2 \sigma)$ have allowed reliable EDS measurements of concentrations of 8 chemical elements ( $\mathrm{Si}, \mathrm{Al}, \mathrm{Mg}, \mathrm{Ca}, \mathrm{K}, \mathrm{Fe}, \mathrm{V}, \mathrm{Ti})$ in ferruginous crust de- bris, which constituted a major part of the studied material. Additionally, 10 thin sections coming from the Upper Jurassic micritic limestones of the Dursztyn Limestone Formation, including 3 of detrital limestones of the Zamkowa Góra Bed, at Zamkowa Góra Mt. were investigated for textural and petrographical features.

The ammonites collected in the Czertezik Succession at Wielka Pustelnica Mt. in years 2002-2018 described herein, are housed in the Museum of the Faculty of Geology of the University of Warsaw (collection no MWG UW ZI/54/43-49).

The study consists of two parts. The first one includes the description of the sections of the Czertezik Succession in its typical development which is based on the new data. The second part presents a critical analysis of the published material presented so far on the facies development of the Jurassic deposits in the Pieniny Klippen Belt in Poland, which provides the basis for the proposal of the new palaeogeography of the area in relation to the revised setting of the Czertezik Succession

\section{DESCRIPTION OF THE CZERTEZIK SUCCESSION}

\section{Spotty limestones and marls (Szopka Limestone For-} mation): Lower Jurassic (Upper Pliensbachian). The oldest deposits attributed herein to the Czertezik Succession are gray-bluish to black spotty limestones and marls which crop out in the narrow ravine running in a WSW-ESE direction along the southern ridge of Wielka Pustelnica Mt., and which descends steeply to Pieniński Creek (Figs. 2-4). These deposits are well-bedded spiculite to radiolarian wackestones, passing locally into spiculite packstones, in the uppermost part only with a minor admixture of small quartz grains (Fig. 2; Pl. 1: A). Dark coloured areas of the limestones contain numerous pyrite framboids ( $\mathrm{Pl}$. 1: B). Some fragments of siderite concretions were also found loose in rubble derived from an exposure of the spotty limestones. The ammonites coming from these deposits were discovered and described by R. Myczyński and localized by him as coming from "outcrops at Pieniński Stream" including "right bank of the Huliński Stream" and "SE slope of Zamkowa Mount" (localities 1a and 1b in sketch-map in: Birkenmajer, Myczyński, 1994, fig. 4). The assemblage of ammonites included: Pleuroceras solare (Phillips), P. cf. spinatum (Bruguière), Arieticeras delcampanoi (Fucini) and Ematiciceras sp. cf. densiradiatum (Gemmelaro) (Birkenmajer, Myczyński, 1994, pl. 1: 2, 3, 5-8; pl. 2: 2-9; pl. 3: 6, 9). It is indicative of the uppermost Pliensbachian Spinatum Zone. It should be remembered that this locality was known also to Horwitz (1937a, b; 1963) who indicated the occurrence of the "Posidonomya shales" yielding Domerian ammonites at the pass between Wielka Pustelnica Mt., and the 


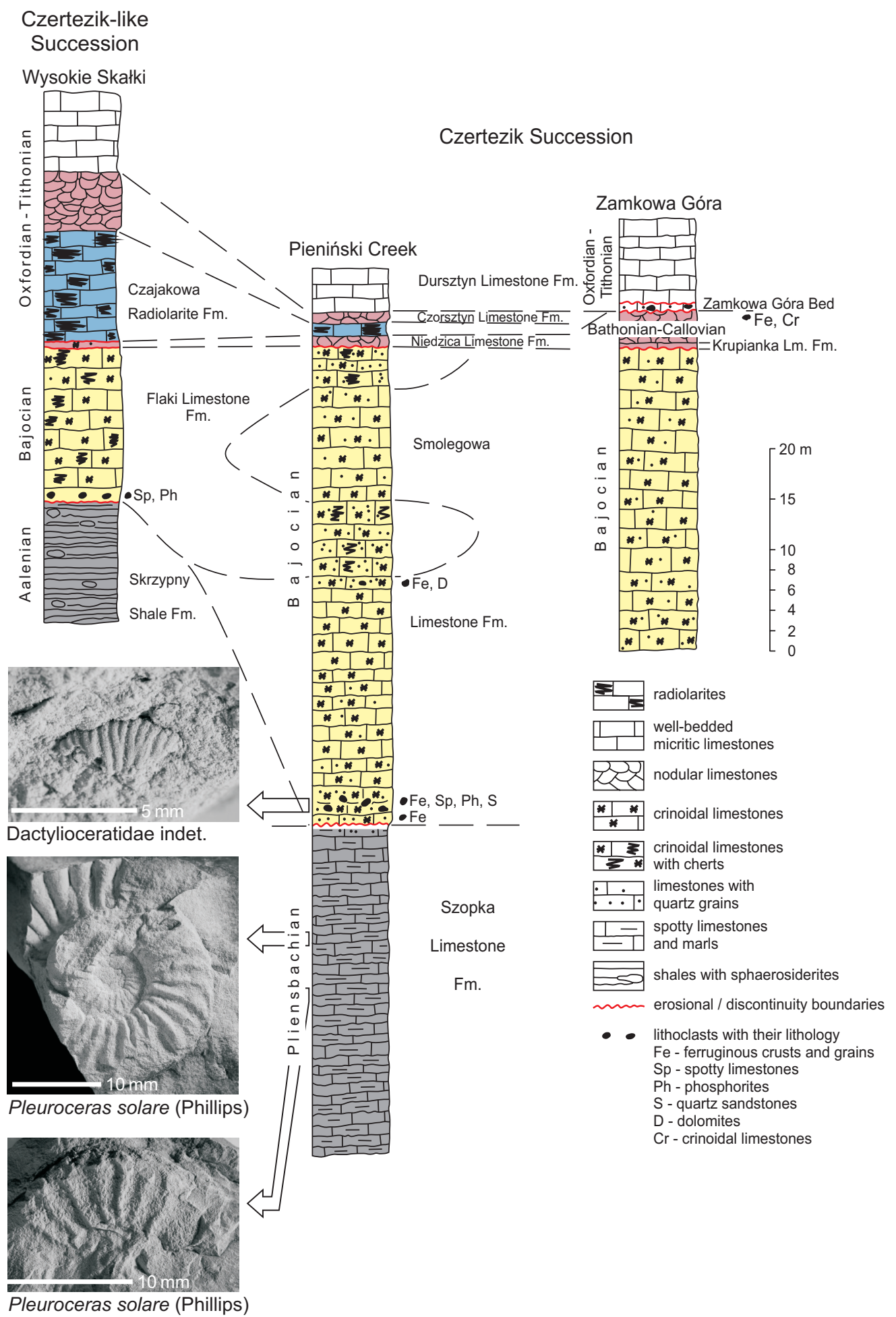

Fig. 2. Lithological logs of the Czertezik Succession (as based on the Pieniński Creek-Wielka Pustelnica to Zamkowa Góra mounts sections) and their correlation with the Czertezik-like section at Wysokie Skałki, based on data presented herein and published by Birkenmajer (1970, 2007) and Wierzbowski et al. (2004: figs 2, 3C; 2009)

Colours of rock-units in accordance with Fig. 6. Photos of selected ammonites of the uppermost Pliensbachian and Toarcian with their position in the section are given ( $P$. solare - MWG UW ZI/54/43-44 and Dactylioceratidae - MWG UW ZI/54/49) 

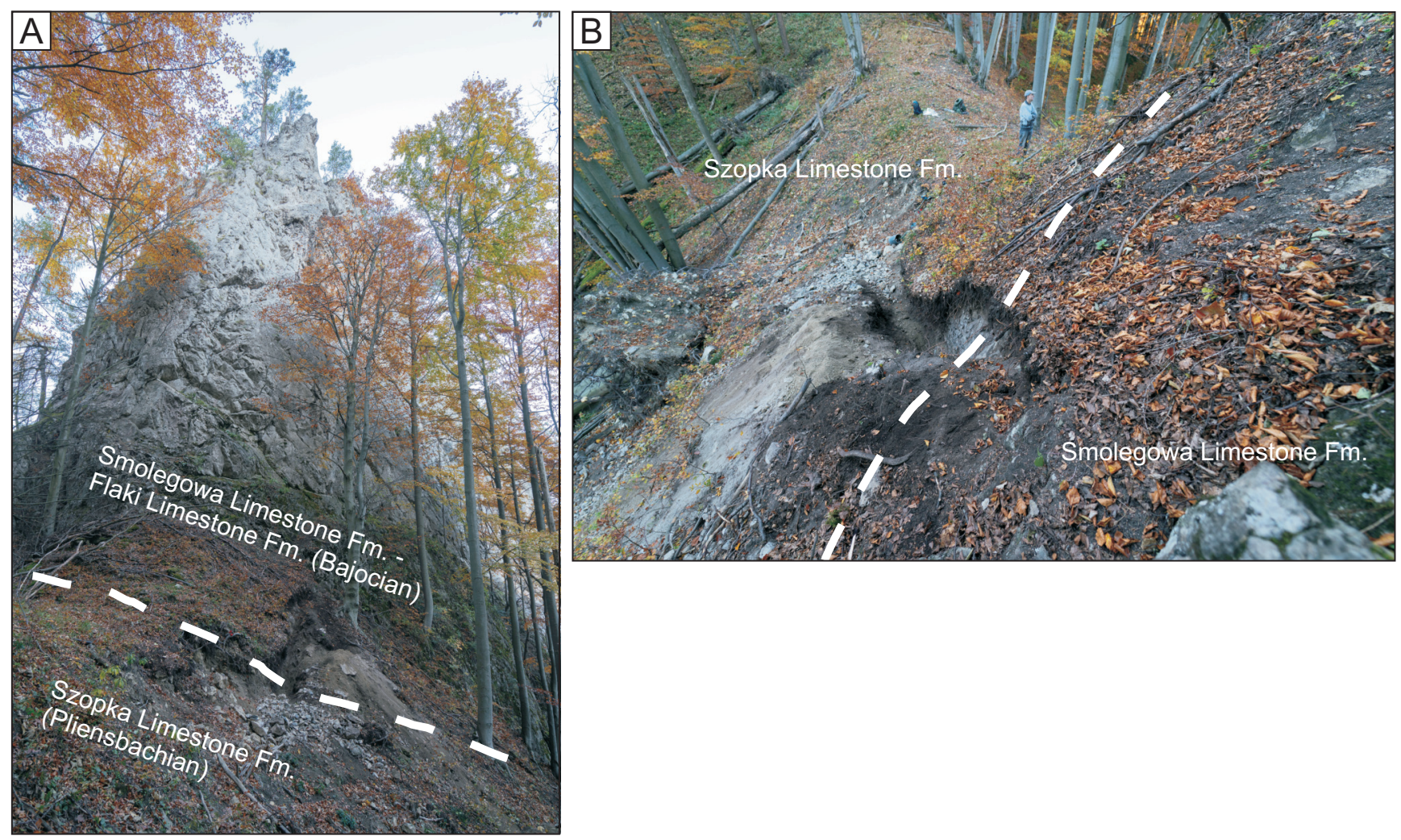

Fig. 3A. Wielka Pustelnica Mt as seen from the north of Zamkowa Góra Mt., boundary between spotty limestones (Szopka Limestone Fm.) and crinoidal limestones (Smolegowa Limestone Fm.) is indicated; B. Locality at the hollow left by a fallen tree (seen in A) on the pass between Wielka Pustelnica and Zamkowa Góra mounts where the tectonic contact between spotty limestones and crinoidal limestones is observed

Pustelnia locality at the western part of Zamkowa Góra Mt. The ammonite collected and described by him from here as "Amaltheus (?) (Paltopleuroceras ?) aff. spinatus var. nudus Bruguière" (Horwitz, 1937b) is Pleuroceras spinatum Bruguière after the revision of Myczyński (in: Birkenmajer, Myczyński, 1994, p. 229) and indicates the Spinatum Zone. A similar assemblage of ammonites (Fig. 2) was discovered here by the present authors and includes: Pleuroceras solare (Phillips), P. cf. spinatum (Bruguière), P. sp. (ex gr. P. apyrenum (Buckman), Amauroceras sp. This assemblage suggests the presence of the Apyrenum Subzone of the Spinatum Zone, and especially its upper part - the Pleuroceras solare horizon (cf. Dommergues et al., 1997).

The highest place of occurrence of the discussed spotty limestones and marls recognized by the authors is in the pass between Zamkowa Góra Mt., and Wielka Pustelnica Mt. (Figs. 3, 4) where they dip almost vertically and strike at azimuth $110^{\circ}$, attaining at least about 25 meters in thickness. They continue from that place along the ravine, and are well seen in its lowest part directly above Pieniński Creek, where they show a similar tectonic position. The general elongated zone of occurrence of these deposits corresponds thus to the ravine (according approximately also to Myczyński’s observation, but possibly includes also outcrops studied by him north-west of Zamkowa Góra Mt., see above) bordered by ridges of the Middle Jurassic crinoidal limestones.

The Lower Jurassic spotty limestones and marls occurring in the Pieniny Klippen Belt in Poland were attributed by Birkenmajer (2008) to the newly erected Szopka Limestone Formation which was recognized by him as occurring "predominantly in the Pieniny Succession". When discussing the distribution of the Szopka Limestone Formation, Birkenmajer (2008, p. 232) attributed to this unit i.a. the Lower Jurassic spotty limestones occurring also "as far east as the Huliński Potok creek, the Zamkowa Góra Mt. and the Potok Pieniński creek". These deposits were interpreted as representing the Pieniny Succession thrusted over the Czertezik unit (Birkenmajer, 2008, fig. 3). However, the two places of occurrence of these deposits indicated by this author do not correspond mostly to that discussed above: these deposits had to occur north-west of Zamkowa Góra Mt., and north-east of Wielka Pustelnica Mt. (Birkenmajer, 2007, fig. 15; 2008, fig. 3). Only the latter occurrence was interpreted in detail by Birkenmajer (2007, fig. 10B; see also 


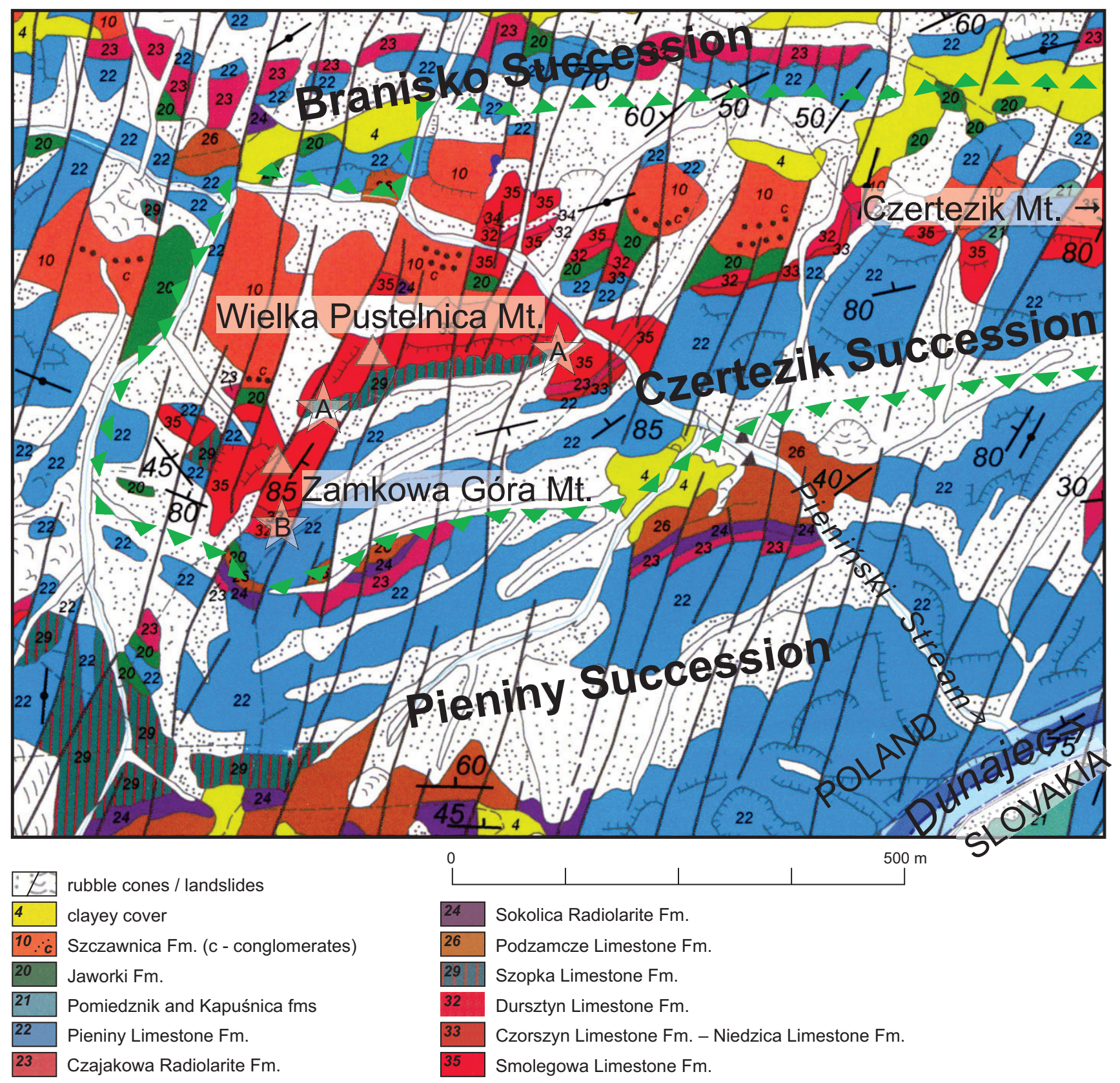

\section{Studied sites:}

A - Szopka Limestone Fm. and basal Smolegowa Limestone Fm.

B - Zamkowa Góra Bed

A - Czertezik - Zamkowa Góra Tectonic Window

Fig. 4. Geological map of the area of study showing the Czertezik Succession appearing in the Czertezik - Zamkowa Góra Tectonic Window (or Pieniński Potok Tectonic Window) from below the over-thrust deposits of the Branisko (southern type) - Pieniny successions of the Pieniny Nappe (after Birkenmajer 2017, supplemented from Birkenmajer, 2007, somewhat modified)

Birkenmajer, 2017, section VII, VIII) as showing the "Upper Liassic spotty limestones" of the Pieniny Succession thrusted over red marls of the Jaworki Formation (Upper
Cretaceous) of the Czertezik Succession, and both tectonically wedged in between large blocks of the Middle Jurassic crinoidal limestones of the Smolegowa Limestone For- 
mation of the Czertezik Succession. However, in the recently published $1: 10,000$ geological map of the Pieniny National Park (Birkenmajer, 2017) the occurrence of the Lower Jurassic spotty limestones is not confirmed in that place, and instead of these there are shown deposits of the Szczawnica Formation (Palaeogene) directly overlying red marls of the Jaworki Fm. In agreement with this, the study of the present authors has not confirmed the occurrence of the Lower Jurassic spotty limestones in the place discussed (Fig. 4).

These observations strongly suggest that there is no tectonic argument in favor of the interpretation of the Lower Jurassic spotty limestones and marls in the Zamkowa Góra - Wielka Pustelnica area as being the deposits of the Pieniny Succession thrusted over the Czertezik Succession. Remarkable is also the occurrence of the Lower Jurassic spotty limestones in the ravine along Wielka Pustelnica Mt., as discussed above, which has not been shown in any detailed geological map by Birkenmajer (2007, fig. 15; 2008, fig. 3; 2017, map); instead in all these maps this area is shown as covered by Quaternary deposits (mostly weathered rubble cones), which occur in between crinoidal limestones of the Smolegowa Limestone Fm. of the Czertezik Succession (Birkenmajer, 2017). The strongest reason for the affiliation of the discussed spotty limestones and marls into the Czertezik Succession comes, however, from the detailed sedimentological analysis of clasts occurring in the oldest Middle Jurassic crinoidal limestones in the study area (Wierzbowski et al., 2019; see also below).

Crinoidal limestones (Smolegowa Limestone Formation - Flaki Limestone Formation) and older redeposited rock units: Lower (Toarcian) to Middle Jurassic (Bajocian). The crinoidal limestones occurring at Wielka Pustelnica Mt., and the Pieniński Creek gorge were studied in detail by Wierzbowski et al. (2004). They are represented by crinoidal grainstones of the Smolegowa Limestone Formation interfingering with crinoid-spiculite grainstones with cherts of the Flaki Limestone Formation, and attaining at least about 44 meters in thickness in the Pieniński Creek gorge (section A according to Wierzbowski et al., 2004), although their base had not been recognized at that time. The crinoidal limestones show here the common, but variable occurrence of detrital quartz grains, and locally yellow dolomite clasts. Such a detrital admixture in the Middle Jurassic crinoidal limestones of the Pieniny Klippen Belt has been usually interpreted as coming from the erosion of older, mostly Triassic deposits (Mišík, Aubrecht, 1994). The lowermost part of the crinoidal limestones was discovered later in the Pieniński Creek Gorge (section B of Wierzbowski et al., 2004) and briefly described by Wierzbowski et al. (2019). It was recognized in two places in the ravine along Wielka Pustelnica Mt., both at its edges at the contact with the discussed Lower Jurassic spotty limestones and marls of the Szopka Limestone Formation (Figs. 2-4): (1) in the pass between Zamkowa Góra Mt., and Wielka Pustelnica Mt. (N 49 $25^{\prime} 18.3^{\prime \prime}$, E $20^{\circ} 25^{\prime} 21.6^{\prime \prime}$ ), and (2) in the lowest part of the ravine directly above Pieniński Creek (N 49²5'17.93", E $\left.20^{\circ} 25^{\prime} 30^{\prime \prime}\right)$. It differs markedly in its lithology from the upper part of the crinoidal unit.

The contact between the Lower Jurassic spotty limestones and marls and the discussed crinoidal limestones is not visible but is undoubtedly of erosional character, at least partly tectonically disturbed, as it was observed in a deepened hollow left by a fallen tree in 2019 in the pass between Zamkowa Góra Mt., and Wielka Pustelnica Mt. (Fig. 3). The uppermost part of the spotty limestones is locally tectonically disturbed and recrystallized with common calcite veins. The well-visible lowermost, $0.3-0.4 \mathrm{~m}$ thick part of the crinoidal limestones exposed between Zamkowa Góra Mt., and Wielka Pustelnica Mt. is composed of dark-gray crinoidal grainstones (locally transitional to quartz sandstones) rich in crinoidal ossicles, quartz grains and less numerous fragments of ferruginous crusts and spiculite wackestones similar to the Lower Jurassic spotty limestones (Fig. 2). This part of the crinoidal limestones also contains scattered pyrite grains (Pl. 1: C, D). The overlying crinoidal limestones (about $4.3 \mathrm{~m}$ thick) are represented in both localities by whitish and reddish or greenish, in the lowest part, crinoidal grainstones very rich in lithoclasts, strongly diversified in their character, and differing markedly from those recognized in the higher part of the crinoidal limestone succession of Wielka Pustelnica Mt. ( $c f$. Wierzbowski et al., 2004). The lithoclasts attaining up to $1-2 \mathrm{~cm}$ in diameters, often with sharp edges, include: (1) fragments of spiculite wackestones very similar in lithology to the Lower Jurassic spotty limestones discussed above (P1. 1: E, F), some of them are strongly recrystallized and devoid of primary microstructures (P1. 1: F), (2) red ferruginous (hematite) grains and crystal aggregates (P1. 2: A, B), (3) yellowgreen fragments of ferruginous crusts and/or large oncoids, which consist of iron hydroxides (mostly limonite) and aluminosilicates similar to Fe-chlorite, and (4) dark phosphorites (Pl. 2: C, D), and (5) abundant quartz grains and fragments of quartz sandstones (Pl. 2: E). The rock also contains an unwashed carbonate matrix. Interestingly, fragments of recrystallized organodetrital wackestones similar to the Lower Jurassic spotty limestones are also found in the higher part of the crinoidal limestones of Wielka Pustelnica Mt. (in bed 18 of the section A described by Wierzbowski et al., 2004; see P1. 2: F).

The EDS studies have revealed the presence of three groups of ferruginous clasts: the red ones are composed of almost pure iron oxide (hematite) and characterized by high iron content ( $\mathrm{Fe} \sim 66.7$ wt.\%), low concentrations of silicon 
( $\mathrm{Si} \sim 1.3$ wt.\%), aluminium ( $\mathrm{Al} \sim 0.7$ wt. $\%$ ) and magnesium (Mg $\sim 0.1$ wt.\%; Fig. 5A). The presence of hematite grains is confirmed by polarizing light microscope studies of thin sections (Pl. 2: A). The second group of clasts is predominantly composed of iron hydroxides of chemistry similar to limonite ( $\mathrm{Fe} \sim 53.8$ wt. \%) with admixture of alluminosilicates ( $\mathrm{Si} \sim 5.0$ wt. $\%, \mathrm{Al} \sim 2.8$ wt. $\%, \mathrm{Mg} \sim 0.8$ wt.\%; Fig. $5 \mathrm{~B}$ ). Another group mostly consists of alluminosilicates, whose composition is close to Fe-chlorites, i.e. chamosite (Fe $\sim 29.4$ wt.\%, $\mathrm{Si} \sim 11.4$ wt.\%, Al 8.6 wt.\%; Mg 5.3 wt.\% Fig. 5C; Pl. 3: A, B). The chemical composition of all the studied ferruginous clasts is similar to the composition of the Lower Toarcian laminated iron deposits, underlying Mn-ore beds, in the Krížna Nappe of the Tatra mountains and the Middle Toarcian - Aalenian iron oncoids from the same area (Jach, Dudek, 2005; Gradziński et al., 2004, 2006). The macroscopic features of the studied grains bear a strong resemblance to Toarcian ferruginous crusts from the Priborzhavske section of the Ukrainian part of the Pieniny Klippen Belt (cf. Wierzbowski et al., 2012). Detailed analysis of the alluminosilicate phases of ferruginous grains should, in the future, be supported by the X-ray diffraction method. The EDS studies have also revealed the presence of small pyrite grains within some hematite clasts from the lower part of the crinoidal limestones and in one case a cinnabar grain. In addition, fine zircon grains occur sporadically between larger quartz grains of the crinoidal limestones.

Although crinoidal limestones with abundant lithoclasts similar to those described above have not been directly recognized before from the study area, some suggestions on their occurrence may be found, however, in the geological literature. Birkenmajer (2007, fig. 10B, p. 20) distinguished a "crinoidal limestone breccia consisting of angular clasts of white crinoidal limestones in red haematitic matrix" (and treated it as a neptunian dyke) within the crinoidal limestones of the Smolegowa Limestone Formation on the right bank of the Pieniński Creek valley; this intercalation was reinterpreted later (Birkenmajer, 2017, section VII, VIII) as a layer of red crinoidal limestones of the Krupianka Limestone Formation. Possibly similar in character is the intercalation of the Krupianka Limestone Formation within crinoidal limestones of the Smolegowa Limestone Formation on the left bank of the Pieniński Creek valley (Birkenmajer, 2017, map). Also the presence of red matrix along with the occurrence of small chlorite grains in crinoidal limestones in a higher part of the Smolegowa Limestone Formation (beds 1/5b and 3/18-19 of section A in: Wierzbowski et al., 2004) in the Pieniński Creek valley may be possibly referred to markedly decomposed ferruginous (hematite-chlorite) clasts.

The succession of deposits of the Czertezik Succession removed by erosion can be reconstructed on the basis of the aforementioned clasts occurring in the lower part of the
Middle Jurassic crinoidal limestones. The oldest are undoubtedly clasts of spotty limestones coming from erosion of the Lower Jurassic limestones of the Szopka Limestone
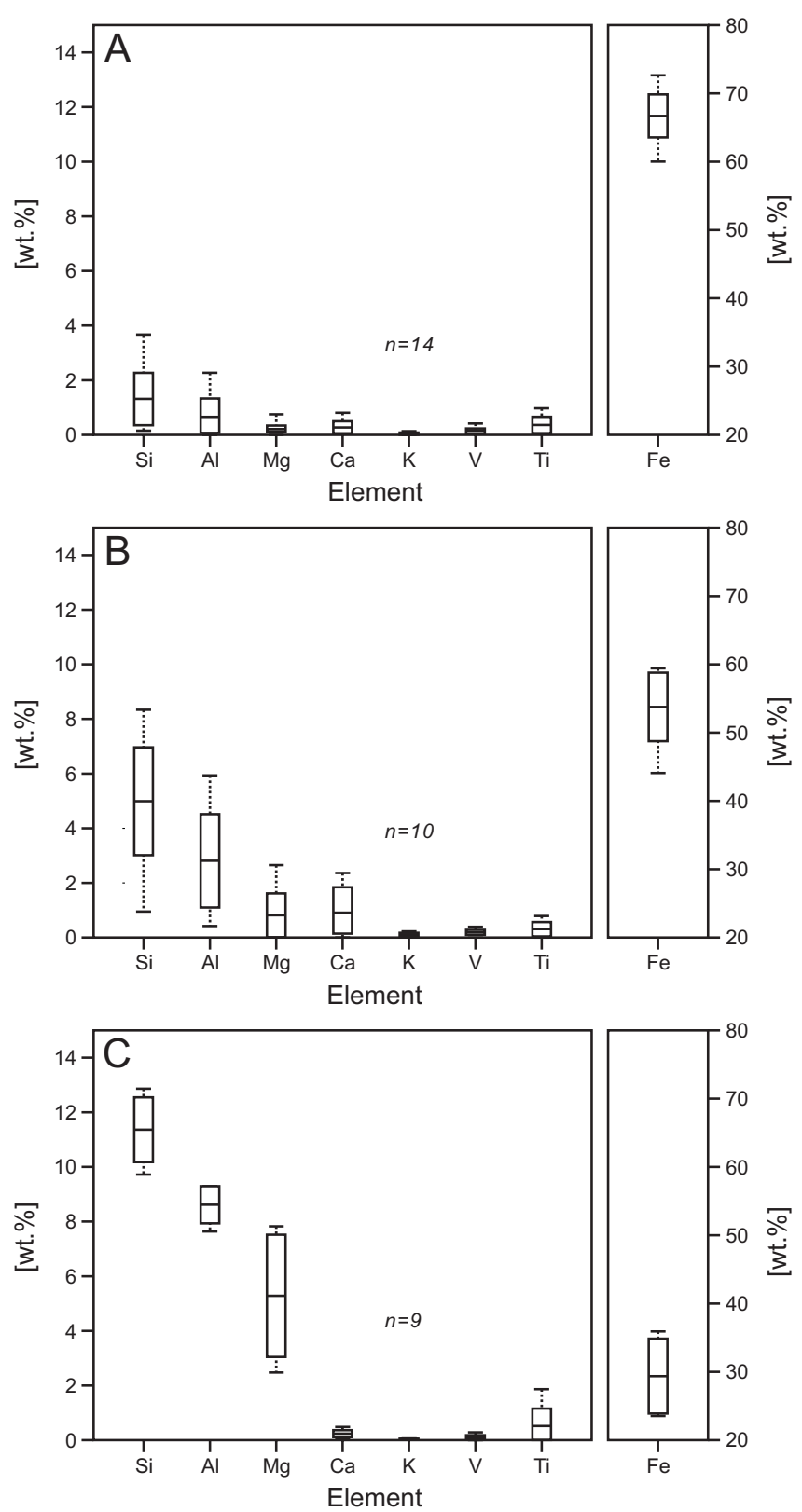

Fig. 5. Concentrations of Si, Al, Mg, Ca, K, V, Ti and Fe in different types of ferruginous clasts from the lowermost part of the Smolegowa Limestone Formation of the Wielka Pustelnica Mt.

A. Chemical composition of clasts composed of almost pure iron oxide (hematite); B. Chemical composition of clasts composed of iron hydroxides of chemistry similar to limonite; C. Chemical composition of alluminosilicate clasts of chemistry similar to Fe-chlorites (chamosite)

Dashed lines - a range of values, rectangles - 1 S.D. limits, black bars average elemental content 
Formation, similar to those described above. Their occurrence is a strong argument for the attribution of spotty limestones and marls occurring in the area of study to the same succession as the crinoidal limestones, i.e. to the Czertezik Succession.

Younger clasts are represented mostly by fragments of red hematite grains and yellow-green ferruginous crusts and/or oncolites. The former yielded a fragment of an ammonite with a few single and biplicate ribs typical of the family Dactylioceratidae (Fig. 2) indicative of the Lower to

$\mathrm{N}$

Subpieniny Nappe

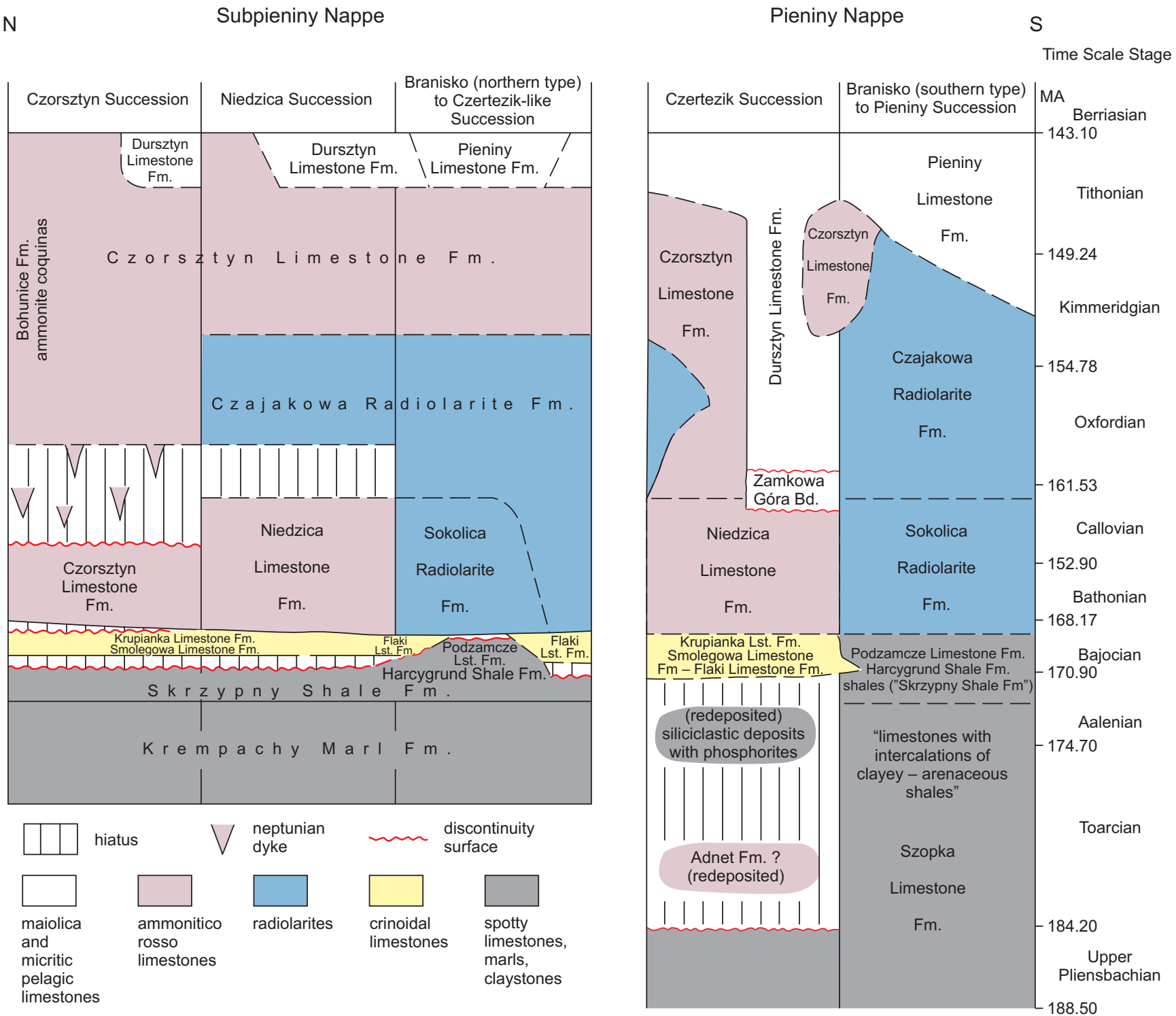

Middle Toarcian (Wierzbowski et al., 2019). Such deposits are not preserved in situ in the area of study, due to erosion which preceded the deposition of the crinoidal limestones (Fig. 6). It is, however, not excluded that fragments of this original cover are still preserved in some inaccessible parts of the area. Similar deposits attributed to the Toarcian are preserved, however, in other parts of the Pieniny Klippen Belt, in the Eastern and Western Slovakia and the Transcarpathian Ukraine (Fig. 1). Red marls with Lower to Upper Toarcian ammonites distinguished as the Hŕbok Formation

Fig. 6. Correlation-scheme of lithostratigraphical units and sketch of the main facies assemblages of the Pieniny Nappe (Pieniny-southern type of the Branisko and Czertezik successions) and the Subpieniny Nappe

(Czertezik-like to northern type of the Branisko, Niedzica and Czorsztyn successions) of the Pieniny Klippen Belt in Poland

The numerical scale of boundaries of the stages is after Hesselbo et al. (2020) 
were described from Beňatina quarry in Eastern Slovakia (Schlögl et al., 2004), whereas reddish and brownish ferruginous, highly condensed limestones with stromatolite encrustations and oncoids referred to the Lower and Middle Toarcian were described from Priboborzhavske quarry in the Transcarpathian Ukraine (Wierzbowski et al., 2012). Red limestones with intercalations of marls yielding Lower to Middle Toarcian ammonites are known also from the Podbiel - Červena Skala section in Western Slovakia (Schlögl et al., 2006; Arabas et al., 2017). All these deposits from Priborzhavske quarry (and other allied ones of Perechin and Novoselitsa in the Transcarpathian Ukraine), as well as those of Beňatina quarry in Eastern Slovakia are attributed to the southern successions of the Pieniny Klippen Belt (Wierzbowski et al., 2012). The Podbiel - Červená Skala section from Western Slovakia is attributed to the Podbiel or the very close Orava Succession, treated as "the transitional units of the Pieniny Klippen basin deposited between the former Czorsztyn Ridge and the Kysuca-Pieniny basin" (Schlögl et al., 2006, p. 83: see also Haško, 1978; Schlögl et al., 2000).

The discussed correlation between the clasts occurring in the crinoidal limestones and the Toarcian deposits as shown above, can be treated also as a key for the reconstruction of the Aalenian deposits in the study area. The Aalenian deposits from Priborshavske quarry are developed either as strongly condensed deposits with abundant fauna and quartz gravels, or more expanded deposits, represented by clays, shales, marls and limestones (Wierzbowski et al., 2012). In Beňatina quarry, they are developed as marly crinoidal limestones and black sandy marls with phosphorites and a marked admixture of detrital quartz grains, attaining about 2 meters in thickness only, and occurring directly below thick crinoidal limestones of Bajocian age (Schlögl et al., 2004). The original occurrence in the study area of fairly thin deposits rich in siliciclasts and containing phosporites, similar to those of the upper part of the Skrzypny Shale Fm. (cf. Tyszka, Kaminski, 1995; Segit, 2010) can be also taken into account, considering that ammonite-constrained Lower Bajocian phosphatic nodules are common in the basal Smolegowa Formation elsewhere (Krobicki, Wierzbowski, 2004). However, the original occurrence in the area of study of thick marly to shaly deposits with subordinate intercalations of limestones of Toarcian to Aalenian age comparable to the Krempachy Marl Formation and the Skrzypne Shale Formation as originally suggested by Birkenmajer in his interpretation of the Czertezik Succession (e.g., 1959, 1977, 2017) seems rather improbable. Such deposits have never been discovered in the area of study being mostly typical of the Czorsztyn to Branisko successions (see also the chapter on comparison between these succession and the Czertezik Succession below). They were never recorded in the Pieniny
Klippen Belt as deposits overlying the condensed ammonitico rosso-type facies deposits (Adnet Fm.?), and moreover no clasts of these deposits (like e.g., limestone clasts which may be attributed to any of these formations) were recognized in the lower part of the crinoidal limestones at Wielka Pustelnica Mt.

When interpreting the section of crinoidal limestones studied at Wielka Pustelnica Mt. from the point of view of recognition of Aalenian deposits, the most plausible solution is that the Aalenian (and/or possibly lowermost Bajocian) deposits, in a similar manner to the Toarcian ones, have been completely eroded and their only remnants are the commonly occurring quartz grains, fragments of quartz sandstones and possibly some phosphorites (Fig. 6). Less likely seems the suggestion given by Wierzbowski et al. (2019) that the lower part of the discussed crinoidal limestones about 4-5 meters in thickness with abundant and diversified clasts is of Aalenian age. Although the detrital material coming from the higher part of the crinoidal limestones of the discussed section is less diversified and shows the predominance of quartz grains, it contains locally also organodetrital wackestones and dolomite clasts ( $c f$. Wierzbowski et al., 2004). In addition, the red colouration of some beds coming from the higher part of the section may be linked to markedly decomposed (and possibly re-deposited) ferruginous (hematitechlorite) clasts. These features suggest the more uniform sedimentological character of the whole set of crinoidal limestones whose origin was strictly related with redeposition processes during the Bajocian. Thus, it is accepted herein that all crinoidal limestones at the Wielka Pustelnica Mt. section belong to the two laterally related lithostratigraphic units - the Smolegowa Limestone Fm./Flaki Limestone Fm. (Fig. 2). Such an interpretation may indicate also that at least some of the phosphorites occurring in the lowermost part of these deposits could be of Bajocian age, similarly as in the described sections of the Smolegowa Limestone Fm./ Flaki Limestone Fm. in the Czorsztyn, Niedzica to Branisko successions (see Krobicki, Wierzbowski, 2004).

The only ammonite found in the higher part of the crinoidal limestones attributed to the Smolegowa Limestone Formation/Flaki Limestone Formation of the Czertezik Succession is Stephanoceras scalare Mascke described by Horwitz (1937b, p. 203, 204, pl. 11: 3; see also Myczyński, 1973, p. 12,17,18), coming from a not precisely indicated place at Pieniński Creek. It is indicative of the upper part of the Lower Bajocian.

Nodular limestones (Niedzica Limestone Fm., Czorsztyn Limestone Fm.), bedded micritic limestones (Dursztyn Limestone Fm.) and radiolarites (Czajakowa Radiolarite Fm.): Middle Jurassic (uppermost Bajocian/ Bathonian) to Upper Jurassic. This stratigraphical interval is represented by the pelagic deposits showing a highly di- 
versified facies pattern in the study area of the Czertezik Succession.

At the Pieniński Creek gorge, the crinoidal limestones of the Smolegowa Limestone Fm. - the Flaki Limestone Fm. are overlain by reddish to greenish nodular limestones. These are represented by packstones to wackestones with the dominant filament (Bositra shell fragments), and filament-juvenile gastropod microfacies, and attain at least 1.25 $\mathrm{m}$ in thickness (upper boundary tectonic). These deposits (Fig. 2), because of their lithology and microfacies type, have been attributed to the Niedzica Limestone Formation, and assigned to the Middle Jurassic (Wierzbowski et al., 2004, figs 2A-C; see also Wierzbowski et al., 1999). In the neighboring section in Pieniński Creek (Wierzbowski et al., 2004, fig 2D, E), nodular limestones of the Niedzica Limestone Formation, about $1.25 \mathrm{~m}$ thick, represented by the wackestone to packstone filament microfacies, and resting directly on crinoidal limestones, are overlain by red and green radiolarites of the Czajakowa Radiolarite Formation. The deposits continue towards the east and have been studied near the tourist trail at Czertezik Mt. where strongly tectonically reduced nodular limestones rest on crinoidal limestones. These nodular limestones consist in their lower part, about $1 \mathrm{~m}$ thick, of packstones rich in filaments, generally similar to those described above, and thus corresponding to the Niedzica Limestone Formation (Wierzbowski et al., 2004). The upper part of the nodular limestones show another microfacies consisting mostly of Saccocoma debris. This type of microfacies is typical of the Czorsztyn Limestone Formation (Wierzbowski et al., 1999), so these limestones can be attributed to this formation, which corresponds stratigraphically to the Kimmeridgian or even the Lower Tithonian. The contact between the upper part and the lower part of the nodular limestones at Czertezik Mt. has a tectonic character and because of that the intervening radiolarites of the Czajakowa Radiolarite Formation have not been observed in this section (Wierzbowski et al., 2004). Additionally, nodular limestones occur both below and above a thin (0.5-1.0 $\mathrm{m}$ in thickness) bed of radiolarites in the fallen klippe of Czertezik Mt. at Zawiesy (Krobicki, Wierzbowski, 2009, fig. 1; see "klippe C" in Birkenmajer, 2007, fig. 15). The lower nodular limestones recognized here and attributed to the Niedzica Limestone Fm., yielded ammonites: Parkinsonia parkinsoni (Sowerby) and Oxycerites sp. indicative of the uppermost Bajocian (Krobicki, Wierzbowski, 2009, fig. 4). The small thickness of the radiolarite unit may suggest its local disappearance which is in part in accordance with the opinion of Birkenmajer (2007, fig. 15; 2017, map) who marks in that place only a uniform set of nodular limestones attributed by him to the Czorsztyn Limestone Fm., and lying directly on crinoidal limestones.
It should be remembered that radiolarites of the Czajakowa Radiolarite Formation of the Czertezik Succession have been recognized also by Birkenmajer (2007, fig. 15; 2017, map) in the sections at Czertezik Mt. Here, similar to Pieniński Creek, they were marked as lying commonly in sedimentary continuity directly on the crinoidal limestones of the Smolegowa Limestone Fm. - Flaki Limestone Fm., or the Krupianka Limestone Fm., without the intervening nodular limestones of the Niedzica Limestone Fm. Although Birkenmajer $(2007$, p. 24, 25) omitted the occurrence of the Niedzica Limestone Formation in this area (possibly because of its small thickness overlooked by him during the field studies), both the microfacies type of the deposits and the ammonite findings discussed above, unequivocally prove its occurrence here.

Younger Upper Jurassic deposits recognized in some sections of the study area are white micritic limestones, a few meters in thickness, occurring below whitish limestones with cherts of the maiolica facies of the Pieniny Limestone Formation. These micritic limestones were attributed to the Dursztyn Limestone Formation (Birkenmajer, 1977, 2007; see also Figs. 2, 6)); such deposits were recognized in the Pieniński Stream gorge by Birkenmajer (2007, figs 8,9 ), as well as in the klippe at Zawiesy fallen from Czertezik Mt., where they even attain about 10 meters in thickness (Krobicki, Wierzbowski, 2009).

A partly different facies pattern is shown in the southwestern part of the area of study, at the section of Zamkowa Góra Mt., near the tourist trail. The section shows crinoidal limestones attaining at least 30 meters in thickness, at the topmost part (about $1 \mathrm{~m}$ in thickness) reddish and with abundant micritic matrix, representing already the Krupianka Limestone Formation. The overlying nodular limestones are $2.7-3.3 \mathrm{~m}$ in thickness and consist of wackestones and packstones rich in filaments, at the top with juvenile gastropods, radiolarian tests and Globochaete. These deposits, belonging to the Niedzica Limestone Formation (Figs. 2, 6), yielded the ammonite Parkinsonia cf. bomfordi Arkell, found in their lower part, which is indicative of the stratigraphical interval near the Bajocian and Bathonian boundary (Krobicki, Wierzbowski, 2009, fig. 3).

The directly younger deposits of the Zamkowa Góra Mt. section reveal a very peculiar facies development. They begin with a thin-bedded micritic limestone bed, only about $0.5-0.8 \mathrm{~m}$ in thickness, with common radiolarians and planktonic foraminifer tests. It contains numerous detrital quartz grains, as well as some clasts of dolomites and crinoidal limestones, small grains composed possibly of glaucony, but also Fe-chlorites (chamosite), and locally hematite; there occur also fragments of ferruginous crusts containing quartz and glaucony grains (Pl. 4: A-D), encountered especially in the lowermost and upper parts of the bed, close to the bor- 
dering omission surfaces; in the whole bed belemnite rostra are common (Wierzbowski et al., 2009). This bed is recognized herein as a new lithostratigraphical unit - the Zamkowa Góra Bed (Fig. 2; see also appendix for the detailed description of the unit). The overlying deposits are micritic limestones attaining $8.3 \mathrm{~m}$ in thickness: they contain in their lowermost part abundant planktonic foraminifers (up to about $2.5 \mathrm{~m}$ above the base), but still with some admixture of detrital quartz grains (found up to about $1 \mathrm{~m}$ above the base), replaced higher, from about $4.0 \mathrm{~m}$ to $5.5 \mathrm{~m}$, by dominant Saccocoma debris; the first calpionellids appear about 7 meters above the base. All these deposits are attributed to the Dursztyn Limestone Formation (Krobicki, Wierzbowski, 2009), whose lower and middle parts may be treated as the lateral equivalents of the Czajakowa Radiolarite Fm., and the Czorsztyn Limestone Fm., and thus correlated at least with the stratigraphical interval from the Callovian/Oxfordian to the Lower Tithonian (Krobicki, Wierzbowski, 2009). The uppermost part of the deposits coresponds already to the Upper Tithonian as shown by presence of Crassicolaria and Tintinopsella at $7 \mathrm{~m}$, and to the lowermost Berriasian by presence of Calpionella alpina Lorenz at $8.3 \mathrm{~m}$. The small thickness of the deposits attributed to the Upper Tithonian - lowermost Berriasian suggests they are possibly not completely represented. They are in turn overlain by whitish limestones with cherts of the maiolica facies of the Lower Cretaceous Pieniny Limestone Formation (at least $8.5 \mathrm{~m}$ in thickness).

\section{COMPARISON BETWEEN THE CZERTEZIK SUCCESSION AND OTHER JURASSIC SUCCESSIONS OF THE PIENINY KLIPPEN BELT IN POLAND: SEDIMENTOLOGICAL AND PALAEOGEOGRAPHICAL APPROACH}

\author{
GENERAL CRITERIA OF RECOGNITION \\ OF THE CZERTEZIK SUCCESSION \\ AND THE PROBLEMS OF ITS DELIMITATION \\ FROM OTHER SUCCESSIONS
}

\footnotetext{
Status quo: The Czertezik Succession as "intermediate" between the Niedzica and Branisko successions and the distribution of the relevant deposits. Early attempts at distinguishing the Czertezik Succession were generally confined to its definition as a so-called "intermediate" succession founded between the Czorsztyn Succession and the Pieniny Succession, along with other "intermediate" successions, such as the Niedzica Succession and the Branisko Succession, recognized earlier in the Pieniny Klippen
}

Belt in Poland (Birkenmajer, 1953, 1959). The general proposal for the palaeogeographical position of the Czertezik Succession as given before by some authors of the present contribution was "much closer to the Niedzica Succession (but linked also to the Branisko/Kysuca Succession) than to the Czorsztyn Succession" (Wierzbowski et al., 2004, p. 254; see also Krobicki, Wierzbowski, 2009). Although the deposits from Czertezik Mt., Pieniński Creek, and Zamkowa Góra Mt. were always treated as the most typical of the Czertezik Succession (Birkenmajer, 1959, 2007), a more diverse set of sections (and deposits) coming from other areas of the Pieniny Klippen Belt was included in that succession. This applies especially to sections lying in the eastern part of the Pieniny Klippen Belt in Poland in the Małe Pieniny Range, south of Szczawnica and Jaworki, in the Durbaszka Mt.Wysokie Skałki Mt. - Stachurówka Mt. area along the Polish-Slovak border, but also the Litmanowa village section in the neighboring area of Slovakia (see e.g. Birkenmajer, 1959, 1977, 2007). A similar interpretation of these sections was given by Wierzbowski et al. (2004) and Krobicki and Wierzbowski (2009) who also included into the Czertezik Succession some other sections from Eastern Slovakia. In addition, deposits occurring in the central part of the Pieniny Klippen Belt in Poland, in the so-called Ociemne-Sutrówka-Bojków Groń Tectonic Window south of Krościenko, as well as in the Polana pod Macelakiem Tectonic Window were attributed to the Czertezik Succession (Birkenmajer, 2007, fig. 12). It is worth noting that sections at Wspólna Skała and Piekiełko, placed more westward, at the eastern side of the Czorsztyn Dam Lake, for a long time attributed to the Czertezik Succession (Birkenmajer, 1959, 1977) have been later transformed into the Branisko Succession, and recognized as representative of its northern type (Birkenmajer, 2007, 2009).

Such an approach resulted in elaboration in the past of the "universal" lithostratigraphic scheme of the Czertezik Succession which in fact obliterated the existing regional differences in lithological logs of the deposits. Moreover, dependent on the chronostratigraphical interpretation of these deposits, the whole Czertezik Succession was placed palaeogeographically either closer to the Czorsztyn Succession (Birkenmajer, 1977, 2007, 2017) or in between the Niedzica and Branisko successions (Wierzbowski et. al., 2004; Krobicki, Wierzbowski, 2009). This resulted in a vague definition of the Czertezik Succession (Fig. 7).

Czertezik Succession definition as based on its locus typicus. The overall concept of the Czertezik Succession has to be strictly related to the depositional sequence recognized in the typical area of its occurrence between Zamkowa Góra and Czertezik mounts as discussed herein (Figs. 2, 6). When taking into account the data from this area, three particular points distinguishing the succession and making re- 


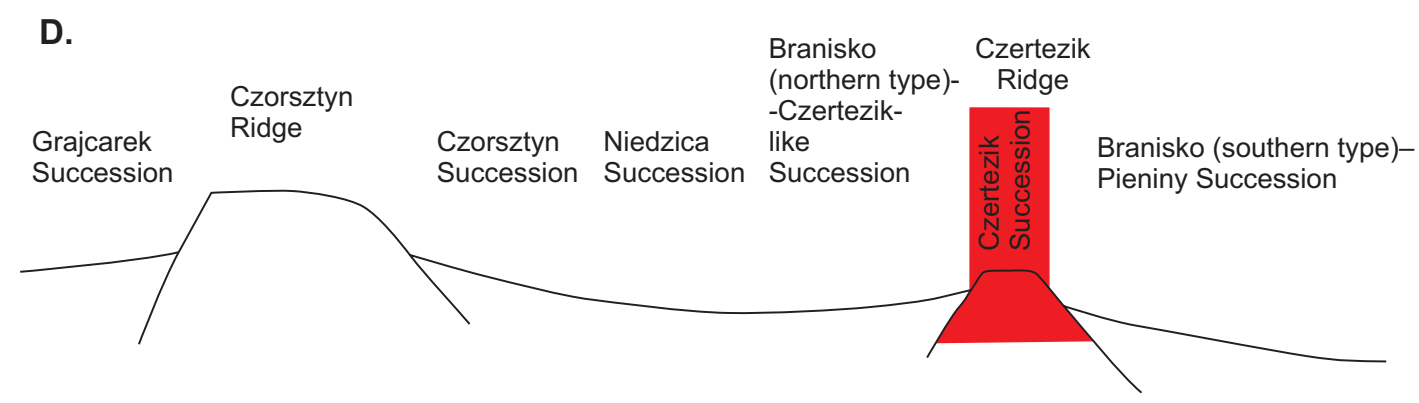

c.

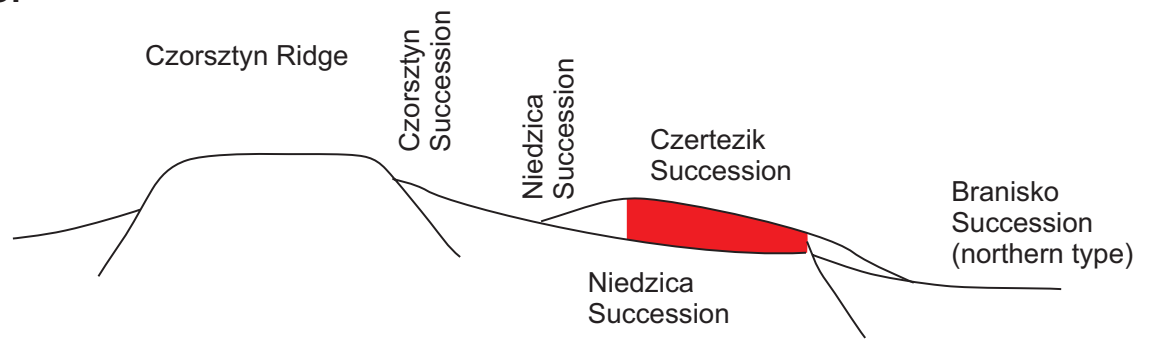

B. $\quad$ Czorsztyn
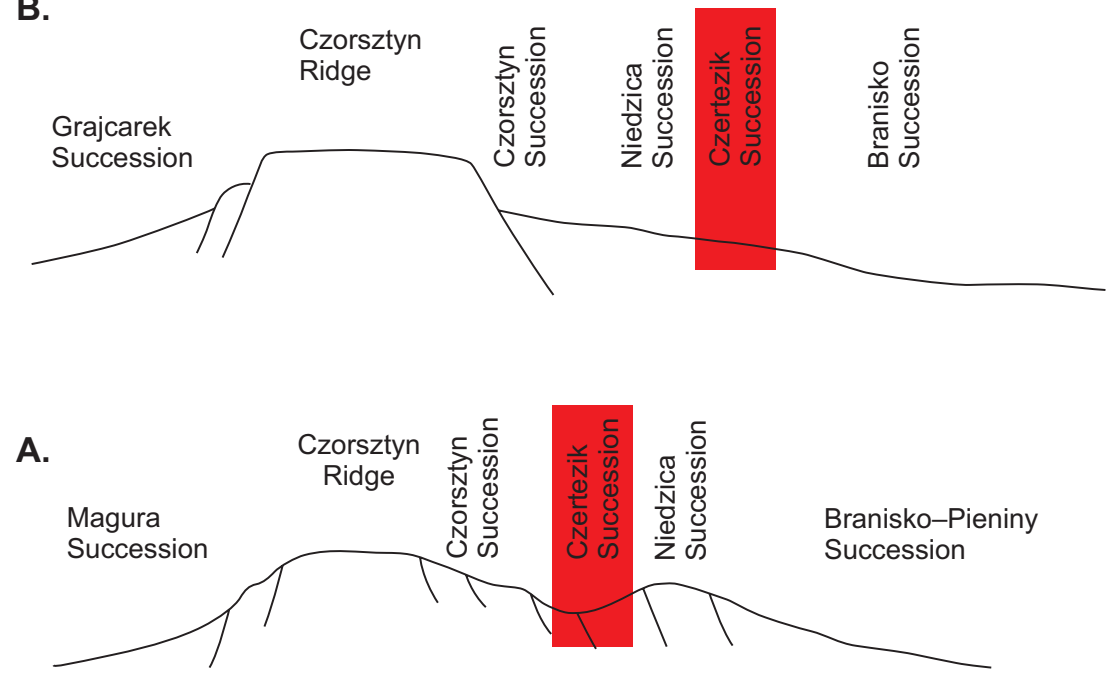

Fig. 7. Palaeogeographic position of the Czertezik Succession in relation to other successions of the Pieniny Klippen Belt in Poland according to various authors

A. After Birkenmajer (1977, fig. 5); B. After Wierzbowski et al. (2004) and Barski et al. (2012, fig. 13); C. After Birkenmajer (2007, fig. 20; 2017, fig. 110); D. As proposed herein, see Fig. 9

lated criticisms of a "universal scheme" of the Czertezik Succession are that:

1. The stratigraphical discontinuity surface which is possibly developed at the top of the spotty limestones of the Szopka Limestone Fm. of the uppermost Pliensbachian. The lowermost part of the crinoidal limestones contains clasts of spotty limestones (Pliensbachian), of ferruginous grains and crusts and/or large oncoids belonging to the ammonitico rosso-type (Adnet Fm.?) (Toarcian), and of siliciclasts and phosphorites (possibly Aalenian/lowermost Bajocian), indicating the original development of rather diversified (and possibly thin) deposits at the Lower to Middle Jurassic boundary. Younger crinoidal limestones attaining at least about 50 or even 60 meters in thickness composed of interfingering crinoid grainstones of the Smolegowa Limestone Fm., and the crinoid-spiculite grainstones with cherts of the Flaki Limestone Fm., were correlated with some higher parts of the 
Lower Bajocian to the Upper Bajocian (Wierzbowski et al., 2004). The shaly-marly deposits of Toarcian-Aalenian age of the Krempachy Marl. Fm., and of the Skrzypny Shale Fm. attaining a few tens of meters in thickness as commonly interpreted before in the "universal scheme" of the Czertezik Succession (e.g., Birkenmajer, 1959, 1977, 2007) possibly never occurred here.

2. The crinoidal limestones as a whole belong to the Bajocian because they are commonly overlain by nodular limestones of the Niedzica Limestone Fm. of latest Bajocian to Bathonian-Callovian age (Krobicki, Wierzbowski, 2009; Wierzbowski et al., 2009), but it should be noted that the occurrence of the latter rock unit was not originally recognized and/or questioned here and the crinoidal limestones were correlated with the stratigraphical interval from the Bajocian to Callovian (Birkenmajer, 1959, 2007, 2017).

3. The overlying radiolarites of the Czajakowa Radiolarite Formation attaining a few meters in thickness range at least from the Upper Callovian (see Wierzbowski et al., 2004; Krobicki, Wierzbowski, 2009) to the Oxfordian. At the boundary between the Callovian and Oxfordian is locally developed a thin micritic limestone unit $(0.5-0.8 \mathrm{~m}$ in thickness) with common radiolarians and planktonic foraminifers, with glaucony, but also Fe-chlorites, and locally also hematite grains, as well as containing detrital (mostly quartz) grains, and crinoidal limestone and dolomite clasts. The occurrence of nodular limestones of the Czorsztyn Limestone Fm., and micritic limestones of the Dursztyn Limestone Fm. partly replacing each other in the Kimmeridgian-Tithonian interval is also proved.

Czertezik Succession as reported from Małe Pieniny

Range. The occurrence of crinoidal limestone units attaining a larger thickness and overlain by radiolarites were the common criteria for recognition of the Czertezik Succession in other areas of the Pieniny Klippen Belt in the past (Birkenmajer, 1959, 1977, 2007, 2017). It was e.g. the case of attribution to the Czertezik Succession of the sections at Stachurówka Mt. and Wysokie Skałki Mt. in the Małe Pieniny Range (Birkenmajer, 1970) which showed also the presence of the Krempachy Marl Fm. (Birkenmajer, 1970). The detailed revision of the sections at Wysokie Skałki (Wierzbowski et al., 2004, fig. 3C) revealed the fairly thick (over $10 \mathrm{~m}$ ) black shales with spherosiderites of the Skrzypny Shale Fm., overlain by crinoidal limestones with cherts (of a rather small thickness ranging from a few up to several meters), corresponding to the Flaki Limestone Fm, and thin red crinoidal limestones of the Krupianka Limestone Fm., covered in turn by radiolarites of the Czajakowa Radiolarite Fm. Younger deposits developed as nodular limestones and overlying micritic limestones (Birkenmajer, 1970) are attributed to the Czorsztyn Limestone Fm., and the Dursztyn
Limestone Fm. (Figs. 2, 6, 8). Occurring in the neighborhood, a sequence at Litmanova in Eastern Slovakia, just outside the state border, shows a marked difference in the development of the crinoidal limestones which can range from about 2 meters to several tens of meters in thickness (Birkenmajer, 2007). They are underlain by the black marly shales with spherosiderites of the Skrzypne Shale Fm. a few tens of meters in thickness, and overlain by a thin $(0.5 \mathrm{~m})$ bed of nodular limestones of the Niedzica Limestone Fm. (Wierzbowski et al., 2004, figs 3C, 6). Some of these deposits yielded a sound palaeontological documentation indicating the Aalenian to earliest Bajocian age of the Skrzypny Shale Fm., the late Early Bajocian age of the lowermost part of crinoidal limestone, and the Oxfordian age of radiolarites (Scheibner, 1964; Ožvoldová et al., 2000; Wierzbowski et al., 2004). Although such deposits were attributed to the Czertezik Succession, they show also a large similarity to the Niedzica-Branisko successions. This was a reason for the opinion that "new data question the necessity of distinguishing the Czertezik Unit as a separate palaeogeographic unit" (Schlögl, Aubrecht, 2009, p. 130), and that the section at the northern part of Litmanova village, showing a small thickness of deposits from the Smolegowa Limestone Fm. to the Dursztyn Limestone Fm., "belongs (...) to the Niedzica Succession” (Birkenmajer, 2007, p. 39).

All these observations indicate that the discussed deposits from the Małe Pieniny Range differ from the typical development of the Czertezik Succession in some features including the presence of the shaly deposits of the Skrzypny Shale Fm., and/or a fairly small thickness of the Bajocian crinoidal limestones. A few sections placed north from Wysokie Skałki and Stachurówka where crinoidal limestones, represented by the Smolegowa Limestone Fm., attain larger thickness (even up to 50-70 meters according to Birkenmajer, 1970), and are overlain by fairly thick red crinoidal limestones of the Krupianka Limestone Fm., and locally even by nodular limestones of the Niedzica Limestone Fm. (Wierzbowski et al., 2004), show some similarity to the Czertezik Succession in its typical development, however, but additional studies are necessary to confirm this suggestion.

Czertezik Succession as reported from the central Pieniny Range (outside locus typicus). There is poor information on the detailed sequence of deposits attributed to the Czertezik Succession in other areas, such as that cropping out fragmentarily in the Ociemne-Sutrówka-Bojków Groń Tectonic Window in the northern part of the Pieniny Klippen Belt near Krościenko. Here thick crinoidal limestone units (both Smolegowa Limestone Fm., and Krupianka Limestone Fm.) are overlain by a few metres thick radiolarites of the Czajakowa Radiolarite Fm. The overlying nodular limestones of the Czorsztyn Limestone Fm. (up to 4 meters 


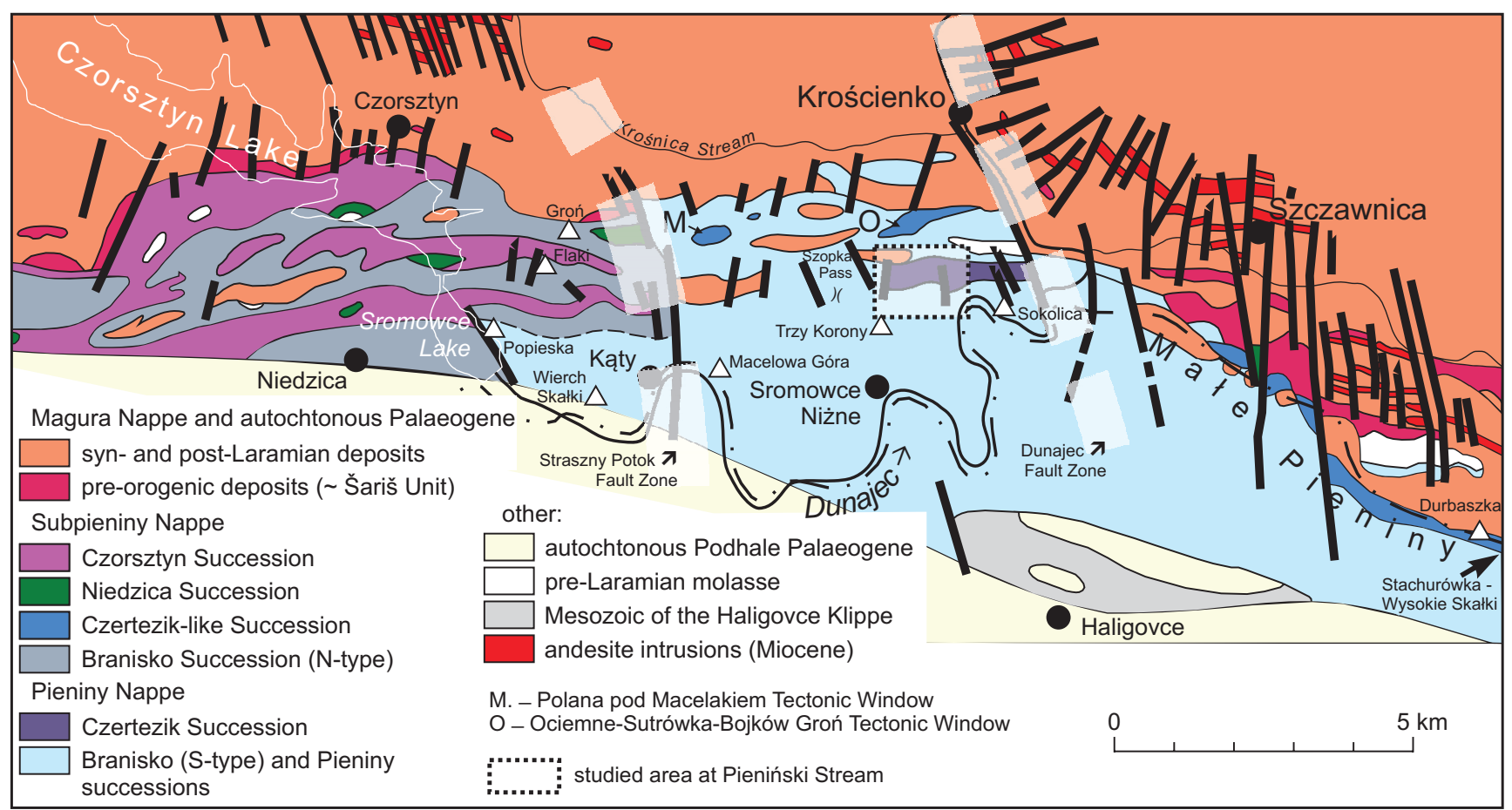

Fig. 8. Tectonic sketch of the central part of the Pieniny Klippen Belt in Poland (after Birkenmajer, 2017, fig. 15; modified)

in thickness) and micritic limestones of the Dursztyn Limestone Fm. (2-4 meters in thickness), are followed by cherty limestones of the Pieniny Limestone Formation attaining at least a few tens of meters in thickness (Birkenmajer, 2007). Another area of occurrence of similar deposits is the Polana pod Macelakiem Tectonic Window. The section of the largest klippe no. 4 in this area (for location see Birkenmajer, 2007, fig. 19) was studied by the present authors (AW, MK): it revealed grey crinoidal limestones (Smolegowa Limestone Fm.) in the rubble, possibly in tectonic contact with younger fine-grained reddish crinoidal limestones overlain by red well-bedded nodular limestones with commonly occurring Saccocoma debris of the Czorsztyn Limestone Fm. (about $5.5 \mathrm{~m}$ in thickness), passing upward into whitish-creamy micritic limestones of the Dursztyn Fm. (at least $5.5 \mathrm{~m}$ in thickness). These sequences resemble those from Stachurówka Mt. and Wysokie Skałki Mt. in the Małe Pieniny Range (Figs. 6, 8).

Czertezik Succession in the new vs. earlier definition. To sum up, the sections of the typical area of occurrence of the Czertezik Succession and those placed outside it, but attributed to this succession in the past, differ clearly in some parts of their lithological logs, especially close to the Lower to Middle Jurassic transition. The difference is especially well seen at the Toarcian-Aalenian stratigraphical interval, which is developed either as the condensed deposits (al- though preserved as reworked material) overlying the spotty limestones of the Szopka Limestone Fm. in the typical area of the Czertezik Succession as discussed herein, or as a coeval expanded sequence of marls, shales and shaly limestones representing the Krempachy Marl Formation and the Skrzypny Shale Formation occurring outside this area. On the other hand, the base of the overlying crinoidal limestones in the latter areas is marked by the common occurrence of clasts of micritic limestones (resembling topmost deposits of the underlying Skrzypny Shale Fm., Segit, 2010; see also Krobicki, Wierzbowski, 2004), pyrite framboids, phosphatic nodules and fossils (brachiopods, belemnites, ammonites) indicative of the upper part of the Lower Bajocian (Wierzbowski et al., 2004). Such a situation is recorded usually in the Branisko, Niedzica and Czorsztyn successions (Krobicki, Wierzbowski, 2004). This set of clasts, with the exception of the phosphatic nodules, differs markedly from that occurring at the base of the crinoidal limestones of the Czertezik Succession at Wielka Pustelnica Mt. The crinoidal limestones occurring outside the typical area of occurrence of the Czertezik Succession are developed similarly to those from its typical area as described above, although their thickness is markedly smaller, and usually does not exceed several meters (Wierzbowski et al., 2004). Regardless of the place of occurrence, however, the upper stratigraphical range of crinoidal limestone units is everywhere similar and it runs 
in the uppermost Bajocian (Wierzbowski et al., 1999, 2004; Krobicki, Wierzbowski, 2004, 2009).

On the other hand, the younger Jurassic pelagic deposits overlying crinoidal limestones in the sections of the typical area of occurrence of the Czertezik Succession, and those occurring elsewhere, show a close similarity in their stratigraphical position and facies development (Fig. 6). This refers to the occurrence of the nodular limestones of the Niedzica Limestone Fm, but also the radiolarites of the Czajakowa Radiolarite Formation and the overlying nodular limestones of the Czorsztyn Limestone Fm. Their development, recognized in the typical area of occurrence of the Czertezik Succession between Pieniński Creek and Czertezik Mt., is very close to that of the Niedzica Succession as described by Birkenmajer (1977), according to the interpretation given by Wierzbowski et al. (2004) and Krobicki, Wierzbowski (2009). In addition, the occurrence of micritic pelagic limestones attributed to the Dursztyn Limestone Fm., which range locally even from the Oxfordian to the Kimmeridgian, but mostly from the Tithonian to the Lower Berriasian, is a typical facies development of both the Czertezik Succession (see above) and the Niedzica Succession (Birkenmajer, 1977).

Specific development of the pelagic deposits, occurring directly above the nodular limestones of the Niedzica Limestone Formation, is recognized, however, in the Czertezik Succession at Zamkowa Góra Mt. (Figs. 2, 6). Their lowermost part is the newly established Zamkowa Góra Bed placed in the Dursztyn Limestone Formation. Another specific feature of the Czertezik Succession in Zamkowa Góra Mt. is the occurrence of micritic limestones of the Dursztyn Limestone Formation ranging already from the Oxfordian and the total absence of radiolarites and younger nodular limestones of the Czorsztyn Limestone Formation (Wierzbowski et al., 2009; Krobicki, Wierzbowski, 2009). Such a development of Upper Jurassic deposits is not encountered so far in locality with this succession except the discussed section of Zamkowa Góra Mt. This indicates that the strongly contrasted facies pattern existed during the Late Jurassic in the typical area of occurrence of the Czertezik Succession.

Palaeogeographic position of the Czertezik Succession and its relation to akin deposits: the Czertezik-like and northern type of the Branisko Succession. The existing differences and similarities between the sequences of deposits attributed to the Czertezik Succession of the typical area of its occurrence, and those lying outside it, need additional comment related to their presumed original palaeogeographic position within the geological framework of the Pieniny Klippen Belt basins in the Jurassic (cf. e.g., Birkenmajer, 1977, 1986). The originally proposed position of all the deposits attributed to the Czertezik Succession indicated its close relation to the Czorsztyn Succession (e.g. Birkenmajer, 1977; see also Fig. 7, herein). According to this interpretation, the submarine fans of crinoidal limestones have been supplied by crinoid ossicles and detrital material coming from the Czorsztyn Ridge (Birkenmajer, 2007, fig. 20; Birkenmajer, 2017, fig. 11), but such an assumption seems very unlikely (Krobicki, Wierzbowski, 2004; Krobicki, 2009). There are several reasons which makes acceptance of a close relationship between the Czorsztyn and Czertezik successions difficult - from marked differences in lithological logs of the deposits attributed to the Czorsztyn Succession, compared with those of the Czertezik Succession (e.g., Wierzbowski et al., 2004), to their different structural position in the Pieniny Klippen Belt: it is remarkable e.g. that the deposits of Czertezik Succession are known only in direct structural relation to higher tectonic units such as the Branisko-Pieniny successions, being not encountered in direct tectonic relation to the Czorsztyn and Niedzica successions (Książkiewicz, 1972; see also Birkenmajer, 2007, p. 40; see also Figs. 1, 8). The deposits typical of the Czertezik Succession, and those showing some similarity to the Czertezik Succession (and attributed in the past to this succession), are known from the inner parts of the Pieniny Klippen Belt, occurring always in a similar tectonic position but placed only somewhat northward or eastward in between (see position of the Czertezik - Zamkowa Góra Tectonic Window or Pieniński Potok Tectonic Window being the typical area of occurrence of the Czertezik Succession, as well as those of the Polana pod Macelakiem Tectonic Window and the Ociemne-Sutrówka-Bojków Groń Tectonic Window, but also the Durbaszka Mt. - Wysokie Skałki Mt. Stachurówka Mt. area of the Małe Pieniny Range; Fig. 8; cf. also Birkenmajer, 2017, fig. 15). It is also worth noting that the occurrences of the discussed deposits are strictly confined to the central and eastern tectonic segments of the Pieniny Klippen Belt in Poland, being delimited from the west by the important tectonic line - the Straszny Potok Fault Zone of the Middle Miocene age, possibly continuing towards north into the Hałuszowski Potok tectonic zone, and cutting through the whole structure of the Pieniny Klippen Belt ( $c f$. Birkenmajer, 2017, geological map). Such a similar tectono-structural position of these occurrences suggests the original close spatial relationship of all the discussed deposits in the Jurassic basin. Westward of the Straszny Potok Fault Zone, the deposits of the Czertezik Succession (but also including those showing some similarity to the Czertezik Succession) are practically not recognized in the Pieniny Klippen Belt in Poland. It is not excluded, however, that the Czertezik Succession (Unit) continues also in that direction, hidden below the thrustzone of the Branisko (southern type) - Pieniny Nappe in southern parts of the Pieniny Klippen Belt. 
The main criteria for recognition of the Czertezik Succession (as based on area of its typical occurrence) are the specific development of deposits at the Lower to Middle Jurassic boundary - including the development of the condensed ammonitico rosso-type (?Adnet Fm.) (which was originally underlain by spotty limestones of the Szopka Limestone Fm. of Pliensbachian age), and the subsequent development of crinoidal limestones of a huge thickness, ranging nearly up to the top of the Bajocian. The deposition of thick crinoidal limestone units during the Bajocian (especially the Smolegowa Limestone Fm./Flaki Limestone Fm., but locally also the Krupianka Limestone Fm.) as seen in typical sections of the Czertezik Succession between Zamkowa Góra and Czertezik mounts resulted from the accelerated accumulation of crinoidal debris at the foot of tectonic escarpments which were settled by "crinoid gardens" ( $c f$. Krobicki, Wierzbowski, 2004), and strong erosion of the older exposed rocks. This together with evidence of earlier elevation of this area as shown by the occurrence of redeposited condensed deposits of the ammonitico rosso-type (?Adnet Fm.) suggests the presence of a submarine elevated ridge (swell) which because of its longer age-span and specific palaeogeographical position had nothing in common with the well-known northern Czorsztyn Ridge (Swell) which originated during the Bajocian (Krobicki, Wierzbowski, 2004).

This assumption suggests also the original close spatial relationship between the elevated area settled by "crinoid gardens" in the Bajocian, being the typical area of occurrence of the Czertezik Succession (and called herein the Czertezik Ridge, $c f$. also Borecka et al., 2013), and the somewhat more distant areas of deposition of crinoidal limestones. It seems highly probable that the latter areas, showing some similarity to the Czertezik Succession (and called herein the Czertezik-like succession) represented the foreland of the Czertezik Ridge, and were supplied by crinoidal and detrital material coming from the ridge (Figs. 6, $7,9)$. These areas could represent some parts of the adjoining basins, thus revealing also some similarity to the northern type of the Branisko Succession (cf. Birkenmajer, 2007, 2009). The crinoidal limestones occurring here, often represented by a variety similar to the Flaki Limestone Fm., were deposited directly on the shales-and-marls of the Krempachy Marl Fm., and Skrzypny Shale Fm.

The details of development of the northern type of the Branisko Succession. It should be remembered that the variety of crinoidal limestones corresponding to the Flaki Limestone Fm. mostly composed of crinoidal limestones with cherts, was recognized as especially characteristic of the so-called northern type of the Branisko Succession in the next to west segment (Czorsztyn-Niedzica one) of the Pieniny Klippen Belt from that recognized as typical of occurrence of the Czertezik Succession. The deposits known here e.g. from the Flaki Range, but also in sections at Wspólna Skała and Piekiełko east of the Czorsztyn Dam Lake, attain even up to 12 meters in thickness (Birkenmajer, 2007, 2009), and some of these sections were even attributed in the past to the Czertezik Succession (Birkenmajer, 1977).

Although the lithological character of the deposits referred to the Flaki Limestone Fm. is almost everywhere similar, its type section at Flaki Mt. (Birkenmajer, 1977)

$\mathrm{N}$

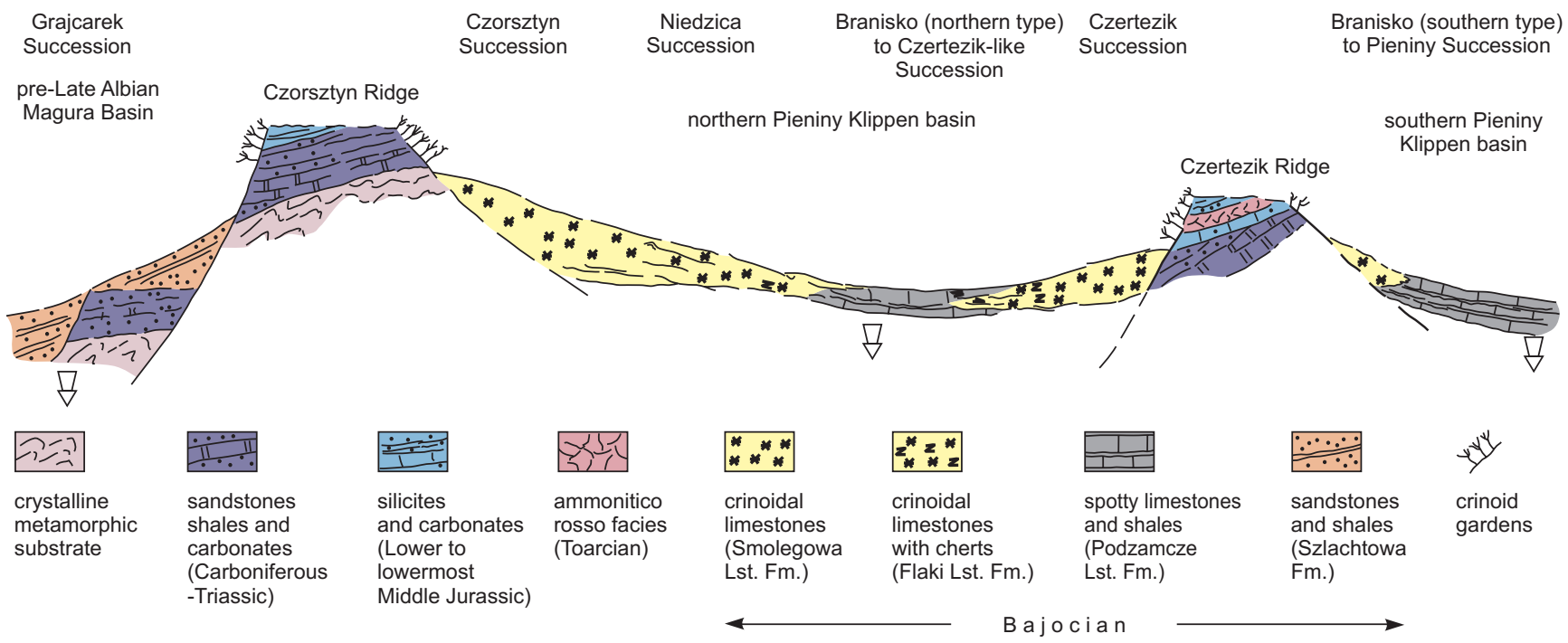

Fig. 9. Palaeogeographic scheme of differentiation of depositional environments in relation to synsedimentary tectonics during the late Early and Late Bajocian (partly after Barski et al., 2012, modified and supplemented) 
shows marked differences in lithology of the deposits. The cherty crinoidal limestones rich in sponge spicules are dominant in the lower part of the section, a few meters in thickness only (Myczyński, 1973; Kasiński et al., 1981). They contain also pyrite concretions, and in the lowermost part also phosphorites which yielded an ammonite indicative of the upper part of the Lower Bajocian (Krobicki, Wierzbowski, 2004). This part of the section can be easily compared with deposits usually attributed to the Flaki Limestone Formation in the Pieniny Klippen Belt, both of the northern type of the Branisko Succession, but also of the Czertezik Succession, and related sections. On the other hand, the middle and upper parts of the Flaki Limestones Fm. in its type section show distinct lithological character and consist mostly of filament limestones and marls with locally redeposited crinoid fragments, sponge spicules and other fossil remains together with quartz grains, chamosite concretions or their fragments. The chamosite concretions found here are generally of small size (up a few centimeters in diameter, but usually smaller) and show the nuclei consisting of different rock fragments - such as pink crinoid limestone, chamositic laminate with stromatolite structure, and crinoidirone ooid limestones. All these organic and inorganic remains were clearly redeposited from shallow-water areas into the deeper-water possibly bathyal environment of the Branisko Succession palaeobathymetric zone (Tyszka, 1995). The unique development of these deposits, not recognized in any other section attributed to the Flaki Limestone Fm., suggests to some degree their similarity to the Niedzica Limestone Fm. (in the common occurrence of filaments and ferruginous concretions). It seems thus possible that the middle and upper parts of the Flaki Mt. section are of latest Bajocian-Bathonian age, being an age correlative of a fragment of the condensed Niedzica Limestone Formation. All these observations indicate unequivocally the necessity of revision of the definition of the Flaki Limestone Fm. in the type section at Flaki Mt. of the northern type of the Branisko Succession to exclude its middle and upper parts as not corresponding to the original definition of this formation for the first time recognized in the Czertezik Succession as "grey crinoidal limestones with cherts" (Birkenmajer, 1959; cf. also Birkenmajer, 1977).

A set of the Middle to Upper Jurassic deposits composed of nodular limestones (Czorsztyn Limestone Fm., locally Niedzica Limestone Fm.) and radiolarites (Czajakowa Radiolarite Fm.), covered/replaced by micritic limestones (Dursztyn Limestone Fm.) is commonly recognized as characteristic of the southern slope of the Czorsztyn Ridge (Birkenmajer, 2017). It is known, moreover, both in the typical area of occurrence of the Czertezik Succession and those placed outside it (but attributed to this succession in the past), but also from the northern type of the Branisko
Succession where radiolarites of the Sokolica Radiolarite Formation additionally occur (Fig. 6). The lateral transition between the Sokolica Radiolarite Fm., and a lower part of the Czajakowa Radiolarite Fm. seems, however, highly probable, as indicated by their stratigraphical contact with underlying crinoidal limestones of Bajocian age (e.g., Wierzbowski et al., 2004), but also by micropalaeontological data (e.g., Gedl, 2008). Such a common character is shown also e.g. by the Jurassic to the earliest Cretaceous deposits at the Piekiełko-Upszar section of the Branisko Succession, showing well-developed nodular limestones of the Czorsztyn Limestone Fm. (7.5 $\mathrm{m}$ in thickness), but including also the younger deposits attributed to the Dursztyn Limestone Fm. by Birkenmajer (1977, fig. 25C). The latter were successively transformed into the Pieniny Limestone Fm., but with the comment that the "limestone resembles very much the Berriasian Sobótka Limestone Mbr. of the Dursztyn Fm." (Birkenmajer, 2009, p. 82). The suggested close spatial relationship between the Czertezik Succession and the northern type of the Branisko Succession thus makes necessary comparison of the Czertezik Succession with other types of the Branisko Succession as well as with the Pieniny Succession.

\section{COMPARISON OF THE CZERTEZIK SUCCESSION AND THE BRANISKO (SOUTHERN TYPE) - PIENINY SUCCESSION}

Palaeotectonic setting. The Branisko and Pieniny successions from the central segment of the Pieniny Klippen Belt in Poland, bordered by the Straszny Potok Fault Zone to the west and the Dunajec (or Krościenko) Fault Zone to the east, form a single Branisko-Pieniny Nappe which is thrust directly on the Czertezik Unit (Succession) in its typical development (Birkenmajer, 2009). The Czertezik Succession (described in the first part of the study) is exposed at the Czertezik-Zamkowa Góra (or Pieniński Potok) Tectonic Window bordered from north and south by the Branisko Succession, and the Pieniny Succession, respectively (Birkenmajer, 2007, 2017; see also Fig. 4). The Palaeocene sandstones and conglomerates rest unconformably on the deposits of all these successions which suggests that a similar structural position existed directly after the Laramian folding and before the Palaeocene transgression (Birkenmajer, 2007). Such a structural situation indicates as highly probable a close palaeogeographic spatial relation between the discussed successions in the Jurassic sedimentary basin, and additionally "suggests also a primary lack of the Niedzica Succession in between these (i.e. Czertezik and Branisko) successions" (Birkenmajer, 2007, p. 44).

Strongly contrasted facies development between the Czerezik Succession and southern type of the Branisko 
to the Pieniny Succession (Pliensbachian-Bajocian). It should be remembered that the deposits of the Branisko Succession occurring in this area differ by their more basinal development when compared to deposits of the northern type of the Branisko Succession (discussed also above) which "resemble those typical for the Niedzica-Czertezik, and Czorsztyn successions" (Birkenmajer, 2009, p. 87). The difference is especially well pronounced by the almost complete lack in the former of the Bajocian crinoidal limestones, and a very poor representation of the nodular limestones (Czorsztyn Limestone Fm.) limited to the thin, from a few centimeters to a few meters in thickness, bedded nodular limestones with cherts of the Upszar Limestone Mbr. (Birkenmajer, 1977). Such development of the Branisko Succession (recognized herein as the southern type of the Branisko Succession) makes it very close to the Pieniny Succession (Fig. 6).

The differences in the Jurassic facies pattern between the Czertezik Succession representing a ridge development and the Pieniny-Branisko (southern type) Succession of the basinal development cannot be treated, thus, as reflecting their separate palaeogeographic and palaeotectonic setting as it was assumed before. In spite of their strongly contrasted facies, the successions seem to be laterally closely related when considering the existing differences as resulting from synsedimentary block faulting.

Spotty limestones of the Szopka Limestone Formation are recognized as the oldest deposits of the Pieniny Succession. They yielded ammonites belonging to several genera (Audaxlytoceras, Aegoceras, Fuciniceras, Ugdulenaia) discovered at Szopka Pass by Myczyński in: Birkenmajer, Myczyński (1994, pl. 1: 1, 4; pl. 2: 1; pl. 3: 1-5, 7). A similar ammonite fauna ["Phylloceras ex. gr. partschi Stuhr = Partschiceras sp., Amaltheus margaritatus Montfort, and "Arieticeras (?) aff. nitescens Young et Bird" = ?Fuciniceras aff. nitescens (Young et Bird)] was described by Horwitz (1937b) and revised by Myczyński (in: Birkenmajer, Myczyński, 1994, p. 229) from the same area at Trzy Korony Mt. The faunal assemblage is indicative of the Margaritatus Zone (mainly its lower part - the Stokesi Subzone, possibly also a higher part - the Gibbosus Subzone) of the Upper Pliensbachian, but additionally including the uppermost part of the underlying Davoei Zone (the Figulinum Subzone) of the uppermost Lower Pliensbachian. Thus, the deposits, although lithologically similar, are older than those occurring between the Zamkowa Góra and Wielka Pustelnica mounts of the Czertezik Succession (Birkenmajer, Myczyński, 1994). Szopka Pass is recognized as the type area of the occurrence of the Szopka Limestone Formation, but the upper boundary of this formation has been defined here as a "transition to the Skrzypny Shale Formation" (Birkenmajer, 2008, p. 233) which makes its position imprecise.
Moreover, the spotty limestones of the Pieniny Succession of the Szopka Limestone Fm. are at least about 80 meters in thickness (lower boundary tectonic). Their upper part is developed as "gray limestones with intercalations of clayeyarenaceous shales", about 40 meters in thickness and not documented by ammonites, in tectonic contact with younger "dark-gray shales with carbonate concretions" as seen at Szopka Pass (Birkenmajer, Myczyński, 1994, fig. 5; Gedl, 2008, fig. 29). Although these youngest deposits have been attributed by Birkenmajer (1977, p. 41) to the Skrzypny Shale Formation, treated as representative of "a northern variety of the Pieniny Succession", such a lithostratigraphic interpretation is going possibly too far (Fig. 6). The Skrzypny Shale Formation is usually developed as black shales and marly clays with spherosiderites containing Upper Aalenian ammonites which overlie the gray marls and shaly limestones of the Krempachy Marl Formation yielding the Upper Toarcian - Lower Aalenian ammonites. Both formations occur in their typical development in the Czorsztyn-Niedzica to northern type of the Branisko successions ( $c f$. Birkenmajer, 1977). Birkenmajer (2008) suggested the Aalenian age of the deposits attributed to the Skrzypny Shale Formation at Szopka Pass (and the Toarcian age of the underlying uppermost Szopka Limestone Formation), but without any sound palaeontological data.

Few occurrences of deposits comparable to those discussed above are known from the southern type of the Branisko Succession in the area of study. Gedl (2008, fig. 30) records after K. Birkenmajer (see also Birkenmajer, 2017, geological map) limestones of the Szopka Limestone Fm., overlain by $2-3 \mathrm{~m}$ of olive-brownish shales attributed to the Skrzypny Shale Fm. cropping out at Biały Potok south-west of Krościenko. All the samples prepared from these deposits for organic dinoflagellate cysts appeared, however, barren (Gedl, 2008). Horwitz (1937a, b) reported the occurrence of the ammonite Aegoceras capricornum Schlotheim, indicative of the Upper Pliensbachian (Domerian), from spotty limestones occurring in a not precisely indicated (and not recognized later, see Birkenmajer, 2017, map) locality, at the Czerteź Alp on left side of the Dunajec river, above the old bridge.

A special unresolved problem is the detailed stratigraphical position of other deposits overlying those of the Szopka Limestone Formation in the Pieniny Succession. As shown in the geological map of the Pieniny National Park (Birkenmajer, 2017), the Szopka Limestone Formation of the Pieniny Succession occurs in the area ranging from Szopka Pass and Wyrobek Alp in the west, and north of Trzy Korony Mt., to Pieniński Creek in the east. The commonly occurring younger deposits in this area are the spotty limestones and marls of the Podzamcze Limestone Formation (see Birkenmajer, 2017, explanation to map and cross-sec- 
tions; see also Birkenmajer, 1965, fig. 1), and locally encountered underlying marly shales attributed to the Harcygrund Shale Formation ( $c f$. Birkenmajer, 2017). The deposits of the Podzamcze Limestone Formation (and the Harcygrund Shale Formation) in the Pieniny Succession are generally attributed to the Bajocian (except its topmost part) as based on correlation with other successions (see Birkenmajer, 1977, 2017; see also Krobicki, Wierzbowski, 2009, fig. 2). It should be remembered that the whole set of deposits of the Pieniny Succession assigned to the Toarcian - Bajocian, which occur above the well-dated Pliensbachian deposits of the Szopka Limestone Formation, is very poorly investigated, and no section of these deposits has been studied in detail. In addition, no palaeontological data, such as those based on ammonites or dinoflagellate cysts, have been ever obtained here (see e.g., Gedl, 2008, figs 25, 28, sites 11, 12).

The stratigraphy of the corresponding deposits of the southern type of the Branisko Succession in the area of study is somewhat better recognized. Myczyński (1973) described gray-bluish spotty limestones with intercalations of shales belonging to the Podzamcze Limestone Fm., and yielding Lower Bajocian ammonites, from the left side of the upper course of the Straszny Potok (Creek) valley. Gedl (2008) described marls and shales of the Harcygrund Shale Fm., and spotty limestones with marly intercalations of the Podzamcze Limestone Fm. exposed at Groń Mt., above Hałuszowa village. These deposits yielded badly preserved dinoflagellate cysts difficult for specific determination, but generally indicative of a Bajocian age for the Podzamcze Limestone Fm., however, the suggested Late Aalenian age of the Harcygrund Shale Fm. (Gedl, 2008, fig. 164) seems here poorly founded.

Regardless of all the problems of detailed stratigraphical correlation, the comparison between the discussed deposits of the Pieniny Succession and the southern type of the Branisko Succession comprising the uppermost part of the Szopka Limestone Formation to the Podzamcze Limestone Formation of Toarcian to Bajocian age, and coeval deposits of the Czertezik Succession, documents marked lateral facies changes (Fig. 6). It applies especially to a transition from the stratigraphically expanded shales and marls of the Pieniny Succession to the condensed (mostly reworked) deposits of the Czertezik Succession in the Toarcian - ?Aalenian. Similarly contrasted deposits are the crinoidal limestones of large thickness commonly recognized in the Bajocian of the Czertezik Succession, and the coeval bedded spotty limestones of the Podzamcze Formation showing only locally thin "tails" of crinoidal limestones in the Branisko Succession (like that at Klenina, south of Hałuszowa where a crinoidal limestone lens is recorded at the boundary between the Harcygrund Shale Fm., and the Podzamcze Limestone Fm., see Birkenmajer, 2017, map and sections).
Facies pattern of the southern type of the Branisko to Pieniny Succession during the latest Bajocian-Tithonian. The younger deposits of the Pieniny and the southern type of the Branisko Succession are siliceous shales and calcareous radiolarites attributed to the Sokolica Radiolarite Formation ("manganese radiolarites") below, and the Czajakowa Radiolarite Formation ("green and red radiolarites") above. They are recognized commonly at several places e.g. at Sokolica Mt. (Birkenmajer, 1977, fig. 23; Gedl, 2008, fig. 28), and at Trzy Korony Mt. (Birkenmajer, 2017, map and section VII, VIII) in the Pieniny Succession, but also in area from the Dunajec River south of Krościenko in the east, to Hałuszowa village in the west, in the Branisko Succession. All these deposits are correlated with a stratigraphical interval from the Upper Bathonian to the Upper OxfordianLower Kimmeridgian, and locally to the Lower Tithonian, as based on study of the organic-walled and calcareous dinoflagellate cyst and radiolarian assemblages mostly in other successions of the Pieniny Klippen Belt (see e.g., Obermajer, 1987; Gedl, 2008; Bąk et al., 2018). These deposits are locally overlain by thin units of nodular limestones of the Czorsztyn Limestone Formation recognized even at the top of the Czajakowa Radiolarite Fm. at Trzy Korony Mt. (Birkenmajer, 1965; 2017, map and section VII, VIII). They range stratigraphically from the Kimmeridgian to the Lower Tithonian. The youngest Jurassic deposits of the Pieniny Succession are whitish to gray limestones with cherts of the maiolica facies corresponding to the Pieniny Limestone Formation. In the well-recognized section at Macelowa Range (Obermajer, 1986) of the Pieniny Succession, the lowest part of these limestones, occurring directly above the Czajakowa Radiolarite Formation, yielded calcareous dinocysts of the Malmica Zone corresponding to the Lower Tithonian. However, in a wider context, the lower boundary of the Pieniny Limestone Formation is evidently diachronous ranging from the Lower Kimmeridgian to the Lower Tithonian (Fig. 6). Such a position of this boundary resulted from the diversified topography of the basin of the Branisko and Pieniny successions: in its deeper parts the sedimentation of the Pieniny Limestone Fm. occurred earlier (from Early Kimmeridgian to earliest Tithonian), directly above the radiolarite unit (which upper boundary has been also diachronous), whereas in its shallower parts, the deposits of the Pieniny Limestone Fm. appeared later (at the end of the Early Tithonian), at the top of the Czorsztyn Limestone Fm. (Hejnar, 2019).

Although the western range of the uniform Branisko (southern type) - Pieniny Nappe has been limited to the Straszny Potok Dislocation Zone, a narrow belt of similarly developed deposits stretches to the west along the southern part of the Pieniny Klippen Belt, up to the Głęboki Creek valley near the Czorsztyn Dam Lake. The most representative for this area are the localities between Kąty village to 
the east (e.g., Kąty locality, see Birkenmajer, 2009), and to the Sromowce Wyżne - up to the Krośnica-Kąty road (e.g., Diabla Skałka and Wierch Skałki, see Kasiński et al., 1981; Ginał, 1998), and to the Popieska Klippe to the west (Myczyński, 1973; Ginał, 1998). The deposits are mostly typical of the southern type of the Branisko Succession and consist of Harcygrund Shale Fm., Podzamcze Limestone Fm. (without any lateral transitions to the Flaki Limestone Fm.), radiolarites (Czajakowa Radiolarite Fm.) and a very characteristic unit of thin-bedded limestones, locally with cherts, of the Czorsztyn Limestone Fm. (referred to the Upszar Limestone Mbr.). The latter is represented commonly by finegrained Saccocoma grainstones enriched at some levels in belemnite rostra, aptychi, quartz grains (Kasiński et al., 1981). These deposits, attaining only to about $1.5 \mathrm{~m}$ in thickness, yielded calacareous dinoflagellate cysts and calpionellids (Crassicolaria) indicative of a long stratigraphical interval from the Upper Kimmeridgian - Lower Tithonian to the Intermedia Zone of the Upper Tithonian (Ginał, 1998). On the other hand, the Popieska Klippe section consists in its lower part of the Harcygrund Shale Fm., and Podzamcze Limestone Fm. (which have yielded Lower Bajocian ammonites, Myczyński, 1973), but in its upper part shows a continuous transition between the Czajakowa Radiolarite Fm. to the Pieniny Limestone Fm., without any indications of the occurrence of the Czorsztyn Limestone Fm., which suggests its possible relation to the Pieniny Succession (Ginał, 1998; see also Fig. 7).

The diversified facies pattern of the southern type of the Branisko-Pieniny Succession in the area of study during the late Middle to Late Jurassic seems to be consistent with that of the Czertezik Succession. It may suggest their continuous lateral transition. The Czertezik Succession shows the dominance of the condensed calcareous deposits formed over elevated parts of the sea-bottom, such as nodular limestones (Niedzica Limestone Formation, Czorsztyn Limestone Formation) and pelagic limestones of the Dursztyn Limestone Formation, with only two marked inclusions of more siliceous deposits: a thin interval corresponding to the Czajakowa Radiolarite Formation (Upper Callovian/Oxfordian) and the chert-rich Pieniny Limestone Formation appearing at the Jurassic/Cretaceous boundary.

\section{FACIES AND STRUCTURAL RELATIONS BETWEEN THE DEVELOPMENT OF THE CZERTEZIK SUCCESSION AND OTHER SUCCESSIONS: DISCUSSION AND CONCLUSIONS}

Origin and early stage of the Czertezik Ridge (Late Pliensbachian-Aalenian/earliest Bajocian). During the late Early Jurassic and early Middle Jurassic, the Pieniny Klip- pen Belt area showed a specific facies pattern which was different from that developed later during the Middle and the Late Jurassic (see e.g., Aubrecht et al., 1997; Schlögl et al., 2004; Wierzbowski et al., 2012).

The Upper Pliensbachian in the Czertezik Succession is represented by expanded spotty limestones which originally were covered by the condensed Toarcian and possibly Aalenian - lowermost Bajocian deposits. The Toarcian of the Czertezik Succession is represented in the sections studied at Wielka Pustelnica and Zamkowa Góra mounts by clasts of red grains to yellow-green ferruginous crusts/large oncoids consisting of iron oxides-hydroxides and Fe-chlorites, along with admixture of iron minerals in red marly matrix, which yielded a fragment of an ammonite with a few single and biplicate ribs typical of the family Dactylioceratidae indicative of the Lower to Middle Toarcian. All of them occur in younger crinoidal limestones (Wierzbowski et al., 2019), reworked from the Toarcian deposits of the ammonitico-rosso type (?Adnet Fm.) (Fig. 2). The Aalenian - lowermost Bajocian deposits are poorly documented, originally also of a rather small thickness: they represent possibly another part of the reworked material (quartz gravels, fragments of quartz sandstones, possibly some phosphorites). On the other hand, the Toarcian-Aalenian interval in the Pieniny Succession is represented by the thick, spotty limestones and marls of the Szopka Limestone Fm. and overlying "gray limestones with intercalations of clayey-arenaceous shales" covered by "dark-gray shales with carbonate concretions", all of them markedly above 100 meters in thickness as seen in the section at Szopka Pass (Birkenmajer, Myczyński, 1994; Birkenmajer, 2008; see also Fig. 6). Strongly contrasted facies development during the Toarcian and Aalenian between the Branisko (southern type) - Pieniny Succession and the Czertezik Succession of the study area, assuming their original depositional relationship, could be inferred as based also on data from other areas in the Western Carpathians, such e.g. as those from the Pieniny Klippen Belt of the Transcarpathian Ukraine (Priborzhavske, Perechin and Novoselica; see Wierzbowski et al., 2012), and easternmost Slovakia (Beňatina, see Schlögl et al., 2004). These observation suggest the foundation of the Czertezik Ridge in the studied area took place already during the Toarcian as result of the rifting of the Devin Phase widely recognized in the Western Carpathians which resulted in "the increasing contrasts between the hemipelagic, partly anoxic sedimentation (of spotty limestones/marls) in halfgrabens (Allgäu Fm.), and the deposition of well aerated ammonitico-rosso limestones (Adnet Fm.) at the edges of domino-blocks" (Plašienka, 2003, p. 89; see also Plašienka, 2018).

Upper Toarcian and Aalenian deposits showing a different facies development are known in the northern part (Czorsztyn Succession to northern type of the Branisko Suc- 
cession and the Czertezik-like Succession) of the Pieniny Klippen Belt in Poland where they are well documented by the ammonite fauna (Myczyński, 2004). The deposits are marls and marly limestones with mica flakes and common radiolarians and benthic foraminifers of the Krempachy Marl Fm., which are succeeded by silty shales and clays of the Skrzypny Shale Fm. (Fig. 6). Their thickness is difficult for precise estimation, but ranges probably from some tens of meters to even $100 \mathrm{~m}$ (Birkenmajer, 1977). These deposits yielded abundant and diversified assemblages of organicwalled dinocysts, including continuous admixture of forms clearly redeposited, such as Rhaetogonyaulax rhaetica, indicating lateral influx from the eroded Upper Triassic deposits (Segit, 2010; Segit et al., 2015; see also Gedl, 2008).

Rejuvenation of the Czertezik Ridge and its position in the palaeogeography of the Pieniny Klippen Belt area (Bajocian). The following rifting of the Krasin Phase (see Plašienka, 2003, 2012) during the Early Bajocian resulted in the origin of the Czorsztyn Ridge (Krobicki, Wierzbowski, 2004; Krobicki, 2009, 2018) in the north, which in a similar manner to the rejuvenated Czertezik Ridge in the south, is recorded by the formation of thick crinoidal limestone units.

The Early Bajocian uplift of the Czorsztyn Ridge in the northern part of the Pieniny Klippen basins is clearly marked by a stratigraphical gap directly above the fine siliciclastic deposits (Skrzypny Shale Fm.) sedimentation of which persisted from the Middle Aalenian to the basal Bajocian as proved by ammonite faunas (Myczyński, 2004). This gap includes a large part of the Lower Bajocian in the Czorsztyn to Niedzica successions (and diminishes towards the south within the northern type of the Branisko Succession) because in the overlying crinoidal limestones occur commonly at their base the ammonites of the Propinquans Zone of the upper part of the Lower Bajocian (Krobicki, Wierzbowski, 2004; see also fig. 2 in Krobicki, Wierzbowski, 2009). Associated disturbances of early lithified crinoidal limestones resulted in the formation of scarp-breccias (Krasin Breccia Member) which along with the development of neptunian dykes are indications of synsedimentary tectonic activity (Mišík, 1994; Mišík et al., 1994; Aubrecht, 1997, 2001; Aubrecht et al., 1997; Krobicki, 2009). The emerged Czorsztyn Ridge yielded also numerous fragments of older rocks, mostly of Middle Triassic dolomites, but also with some admixture of other ones, such as sandstones of Permian to Triassic age, to the newly formed crinoidal limestones during the Bajocian (Mišík, Aubrecht, 1994).

A similar tectonic uplift was responsible for development of the thick crinoidal limestone of the Czertezik Succession at the foot of the Czertezik Ridge as recognized at Pieniński Creek and Zamkowa Góra Mt. in the Pieniny Klippen Belt. These are developed as interfingering units of crinoidal grainstones and crinoidal-spiculite wackstones to grainstones with cherts representing the Smolegowa Limestone Fm., and the Flaki Limestone Fm., respectively (Wierzbowski et al., 2004). Also, the detrital admixture in the crinoidal limestones of the Czertezik Succession is akin to that of the Czorsztyn Succession being composed mostly of detrital quartz grains and some dolomite clasts (Wierzbowski et al., 2004), beside their lowermost part showing different rock fragments. Here clasts redeposited from eroded deposits of the Upper Pliensbachian-Toarcian-?Aalenian (as discussed herein) dominate (Fig. 6).

The palaeogeographic spatial relationship of the particular successions shown in Fig. 9 is proposed for the Pieniny Klippen Belt area in the Bajocian. It was the time of strong facies differentiation, whose stratigraphical record is among the most complete.

The southern basin of the area was occupied by the deepwater Pieniny to southern type of the Branisko Succession showing the deposition of the basinal Harcygrund Shale Fm., and the Podzamcze Limestone Fm. (the latter with the occasional occurrence of crinoidal limestones of the Flaki Limestone Fm.). It should be remembered that the southern Branisko-type deposits seem very close to those of the Pieniny Succession, and both of them represent a single tectono-facies zone. The next to the north, the Czertezik Succession, corresponding to the typical area of its occurrence was possibly a rather narrow facies zone limited to the Czertezik Ridge. The ridge was asymmetric with a steep northern face (assuming the west to east stretching facies zones of the particular successions in the Jurassic basin, e.g. Birkenmajer, 1977), where crinoidal limestones of large thickness accumulated. A sharp transition from crinoidal grainstones of the Smolegowa Limestone Fm., to crinoidal-spiculite grainstones with cherts of the Flaki Limestone Fm. suggests a rather sudden change in topography of the sea-bottom from the elevated ridge to the steeply inclined slope of its northern foreland. This area continued further north revealing the transition to the markedly thinner deposits of the Flaki Limestone Fm. The deposits of the Flaki Limestone Fm. rest here with erosional contact directly on the Skrzypny Shale Fm., and represent the deposits attributed so far to the Czertezik Succession, but differing in some features from these deposited at the neighboring Czertezik Ridge, being referred to as the Czertezik-like succession herein.

A marked similarity between the discussed deposits and those representing the northern type of the Branisko Succession is apparent ( $c f$. Birkenmajer, 2007, 2009). Although the latter deposits are known from another tectonic segment of the Pieniny Klippen Belt than the Czertezik Succession, their similarity suggests close proximity to the next northward-oriented zone of the Jurassic basin. The discussed deposits of the northern type of the Branisko Succession were deposited most possibly in the middle of the northern basin 
located in between the Czertezik Ridge in the south and the Czorsztyn Ridge in the north. Just these deposits are likely have the greatest affinity to the "true" Branisko Succession (or Kysuca Succession in Slovakia). The central position of the Branisko Succession is in accordance with its more complete, and more deep-water sequence of deposits during the Bajocian: from the Harcygrund Shale Formation below, and the fine-grained crinoidal limestones with cherts of the Flaki Limestone Fm. of smaller thickness, replaced partly or even totally by basinal Podzamcze Limestone Fm. above (Figs. 6, 9).

Crinoidal limestones belonging to the Smolegowa Limestone Fm. are known from areas placed originally more toward the north: such deposits occur in the Czorsztyn Succession where they can attain a large thickness, and in the Niedzica Succession where their thickness is markedly smaller (Birkenmajer, 2007). The Czorsztyn Succession accumulated in the southern zone of the Czorsztyn Ridge (e.g., Birkenmajer, 1986). This zone represented a rather gentle slope of the ridge (Fig. 6) where "smaller-scale tectonic scarps were settled by crinoid gardens which resulted in the formation of thick units of crinoidal limestones" (Barski et al., 2014, p. 407). On the other hand, the northern steep slope of the Czorsztyn Ridge was the main source for deposition of the "black flysch" deposits (Szlachtowa Fm.) of the Grajcarek Succession, representing already another sedimentary basin (Magura or pre-Late Albian Magura Basin according to Barski et al., 2014; Segit et al., 2015).

When comparing the Czorsztyn Ridge with the newly distinguished Czertezik Ridge, the former was undoubtedly the structure of a larger range and size, being a place of sedimentation of the Bajocian crinoidal limestones in markedly shallower-water zone (Mišík, Aubrecht, 1994; Aubrecht, 1997, 2001; Aubrecht, Sýkora, 1998)).

Thermal subsidence and deposits of an early pelagicstage (latest Bajocian-Middle/Late Oxfordian to earliest Kimmeridgian). The youngest Bajocian as well as the overlying Bathonian to Oxfordian deposition of all the Pieniny Klippen Belt successions occurred in a markedly different palaeotectonic setting corresponding to a moreopen marine deep-water pelagic environment. Such a character is shown in the uppermost Bajocian and Bathonian up to the Callovian/Oxfordian boundary nodular limestones of filament (Bositra) microfacies attaining generally a small thickness. They are known both in the Czorsztyn Ridge, and its southern promontory in the Niedzica Succession in the north, and symmetrically in the Czertezik Ridge in the south, represented in the latter two areas by the Niedzica Limestone Fm. resting over crinoidal limestones (commonly of the Krupianka Limestone Fm.). The occurrence of condensed Bositra nodular limestones of the ammonitico-rosso type marks an important phenomenon in the history of the Pieniny Klippen basins. Their appearance begins the pelagic stage of the structural evolution of the Pieniny Klippen Belt (Birkenmajer, 1986). According to Plašienka (2003, 2012, p. 613) the hiatus at the base of ammonitico-rosso deposits and the occurrence of neptunian dykes in the Czorsztyn Ridge, containing commonly the "filamentous" microfacies (e.g. Aubrecht, Túnyi, 2001; Sidorczuk, 2005) correspond "to an oceanic break-up discordance followed by a pronounced thermal subsidence stage during the BathonianLate Jurassic". The Bositra limestones can also be treated, in relation to taphonomic, ecologic and dissolution factors, as a result of the marked reconstruction of the West Carpathian basins, being "an indicator of the intermediate stage of evolution of the basins towards radiolarite formation' (Jach, 2003, p. 168).

The environmental changes in the basinal deposits of the Branisko Succession (of the northern type as discussed above) are pronounced already in the upper part of the Podzamcze Limestone Fm. where a lighter-colored and more diversified microbenthic assemblage has been recognized, which suggests a stronger activity of sea-currents when compared with lower part of this formation (Tyszka, 1994); a similar conclusion can be drawn from recognition of the omission surfaces covered with belemnite rostra at the top of the Podzamcze Limestone Fm. by Gedl (2008, fig. 36). These deposits are commonly overlain by "manganese radiolarites" of the Sokolica Radiolarite Fm. indicating already an intensive sediment reworking by burrowing organisms at a well-oxygenated sea-floor (Krobicki, Uchman, 2006). The time-relation between the condensed nodular limestones formed over the elevated parts of the sea-bottom, and the basinal radiolarite deposits of the Branisko Succession is difficult for detailed deciphering but several observations suggest their lateral transition. It is e.g. the case of the occurrence of chamosite concretions in filament limestones and marls, which were possibly redeposited from more elevated parts of the basin (being the place of sedimentation of the Niedzica Limestone Fm.). Such deposits occurring directly below the Sokolica Radiolarite Fm. at Flaki Mt., but above the crinoidal limestones with cherts (Tyszka, 1995; see also discussion in the chapter on the general criteria of recognition of the Czertezik Succession, herein), prove the existence of a markedly contrasted topography of the seabottom. It should be remembered that the oldest radiolarites in the Pieniny Klippen Belt belonging to the Sokolica Radiolarite Formation are interpreted as corresponding to the uppermost Bajocian and Bathonian of the Branisko Succession (Gedl, 2008), thus corresponding in age to the nodular limestones of the Niedzica Limestone Fm. of the southern promontory of the Czorsztyn Ridge, and of the Czertezik Ridge.

The stratigraphical interval from the Callovian to the Lower/Middle Oxfordian boundary was a very specific (and often overlooked) time in history of the development of the 
Pieniny Klippen basins. It is characterized by fragmentary preserved deposits, mostly occurring in neptunian dykes, and commonly recognized large stratigraphical gaps, as seen in the Czorsztyn Succession of the Czorsztyn Ridge (Fig. 6): the gaps include e.g. at least a large part of the Callovian, and the Lower Oxfordian as recognized by ammonite faunas in the Velykyi Kamianets (Veliky Kamenets) section of the Transcarpathian Ukraine (Reháková et al., 2011; see also Lewandowski et al., 2005), but also a large part of the Callovian and Lower Oxfordian, as recognized e.g. in Czorsztyn Castle klippe section in Poland (Wierzbowski et al., 1999). The neptunian dykes are filled either with red limestones with commonly occurring filaments which yielded the Callovian ammonites like the "classical" dyke at Babiarzowa (vel Babierzówka) klippe at Nowy Targ in Poland, but also its younger infilling of red limestones with planktonic foraminifer microfacies typical of the Oxfordian (Uhlig, 1881; Wierzbowski et al., 2005); or dykes of Vršatec and Štepnická Skala in Western Slovakia of red limestones containing sometimes filaments with Callovian ammonites, and red limestones with the latest Early to early Middle Oxfordian Boreal ammonites of the genus Cardioceras (see Schlögl et al., 2001, 2009). The overlying Middle to Upper Oxfordian limestones of the Czorsztyn Succession are usually strongly condensed and underlain by ferromanganese crusts. The limestones contain abundant ferromanganese nodules, and show the presence of the planktonic foraminifer microfacies (e.g., Wierzbowski et al., 1999; Hudson et al., 2005; Sidorczuk, Nejbert, 2008). Extremely condensed deposits of the so called Velykyi Kamianets (Veliky-Kamenets)-2 (called sometimes "Maly Kamianets") section of the Czorsztyn Ridge in Transcarpathian Ukraine (Aubrecht et al., 2017) show a very unusual development: the corroded top of the crinoidal limestones bearing signs of temporary emersion is covered here by a thin greenish sandstone layer with angular quartz sand grains, and overlain by nodular limestones with planktonic foraminifer-filament microfacies suggesting the Callovian/Oxfordian transition. The presence of detrital quartz grains is usually not encountered in this stratigraphical interval in the Czorsztyn Succession of the Pieniny Klippen Belt, and it reveals some similarity to the Zamkowa Góra Bed of the Czertezik Succession described below.

The stratigraphical interval at the Callovian-Oxfordian boundary reveals also a very special facies pattern at the Zamkowa Góra section of the Czertezik Ridge in the Pieniny Klippen Belt in Poland. A thin condensed pelagic limestone bed (Zamkowa Góra Bed as distinguished herein; Fig. 2, see also appendix) contains abundant radiolarians and planktonic foraminifers, but it also shows the presence of detrital grains of quartz and dolomite together with fragments of the crinoidal limestones as well as glaucony and Fe-chlorite (chamosite) grains/aggregates and fragments of ferruginous crusts. The unique character of the bed indicates that it originated in a deep-marine pelagic environment temporary supplied by clastic material coming from erosion of the Middle Jurassic crinoidal limestones and the re-deposited ferruginous crusts/nodules formed on elevated parts of the sea-bottom, thus providing evidence for the synsedimentary tectonic activity which produced the active tectonic scarps (Wierzbowski et al., 2009). The origin of the bed indicates thus a similar depositional (and tectonic) pattern to that which existed during the formation of deposits of the Callovian/ Oxfordian boundary at the Czorsztyn Ridge.

The stratigraphical condensation at the Callovian-Oxfordian boundary occurs at the top of the nodular limestones of the Niedzica Limestone Fm. in the Niedzica Succession and possibly in the Czertezik Succession, directly below the onset of the basinal radiolarites of the Czajakowa Radiolarite Fm., which locally range onto the areas covered by nodular limestones and correspond to the elevated parts of a sea-bottom, beginning already from the Middle Oxfordian (Wierzbowski et al., 1999, Ožvoldova et al., 2000; Bąk et al., 2018).

The palaeomagnetic data from the Czorsztyn Succession of the Pieniny Klippen Belt of the Transcarpathian Ukraine (Velykyi Kamianets (Veliky Kamenets) section) and Slovakia indicate a relatively fast opening of the new oceanic domain north of the Czorsztyn Ridge during the Callovian and Early Oxfordian (Lewandowski et al., 2005, 2006). It is consistent with the results of geochemical studies which recorded the entering of more radiogenic (in $\mathrm{Nd}$ and $\mathrm{Sr}$ isotopes) oceanic waters into the Pieniny Klippen Belt area in Poland between the Early Callovian and Middle Oxfordian which suggests a rapid rifting process (Sidorczuk et al., 2009). This oceanic domain corresponds generally to the Magura Ocean whose opening occurred according to Birkenmajer (1986, p. 23) "during Late Liassic or even MidLate Jurassic times to the north of the Czorsztyn Ridge" as a consequence of "a relocation of the rift zone to the north and formation of new oceanic crust". The discussed domain as denoting the oldest ocean of the "Magura-type" was informally named the "pre-Late Albian Magura basin" to distinguish it from the younger Cretaceous-Palaeogene Magura Ocean of the Outer Carpathian zone (see also below). The fragmentarily preserved Bajocian deposits of the Grajcarek Succession in the Pieniny Klippen Belt in Poland, occurring in front of or below the Subpieniny Nappe (Czorsztyn to northern type of the Branisko successions), are just correlated with this old oceanic domain (Barski et al., 2012; Segit et al., 2015). It should be noticed that the opening of this new oceanic domain on the northern side of the Czorsztyn Ridge after the Middle Jurassic rifting of the Krasin Phase was preceded by the Early to Middle Jurassic rifting phases which led to the opening of the South Penninic-Vahicum 
Ocean south of the Pieniny Klippen basins (see e.g., Plašienka, 2003, 2012; Csontos, Vörös, 2004).

The opening of the new oceanic domain is also marked at its northern shelf border in the epiplatform areas of southern Poland. Here, the appearance of condensed pelagic deposits (following the shallow-water ones), the evidence of chemical corrosion of carbonates (interpreted as a consequence of upwelling of cold oceanic waters onto the epiplatform areas), a marked contrast in facies development and changes in thickness of coeval deposits (resulting from synsedimentary tectonic activity) are commonly recognized from the Middle Callovian to the Lower Oxfordian (for references see Matyja, Wierzbowski, 2006; Matyja, 2015). This fairly short-time phenomenon (about $5 \mathrm{Ma}$ ) related to a strong oceanic expansion was distinguished as the "Metis Geotectonic Event" (Matyja, Wierzbowski, 2006).

Switch from condensed to normal deposits of a late pelagic stage (late Early Kimmeridgian-Tithonian). Younger Late Jurassic (late Early Kimmeridgian-Tithonian) ammonitico-rosso deposits (Czorsztyn Limestone Fm., Bohunice Limestone Fm.) of the Pieniny Klippen Belt are characterized initially by an increase in thickness and a change of their microfacies type (from very condensed Oxfordian to earliest Kimmeridgian deposits of the planktonic foraminifer microfacies to more expanded late Early Kimmeridgian to Early Tithonian ones dominated by Sacoccoma debris); successively also by a marked decline of ammonitico-rosso type deposits, and radiolarites, and the domination of the pelagic limestones especially of the Dursztyn Limestone Fm., but also of the Pieniny Limestone Fm. Such a development is observed in the Czorsztyn Succession of the Czorsztyn Ridge where the pelagic limestones attain even up to a few tens of meters in thickness ( $c f$. Birkenmajer, 1977); but then successively through the Niedzica Succession where also radiolarites appear, and to the Branisko Succession (northern type of the Branisko Succession and the Czertezik-like succession, as interpreted herein), where the radiolarites and pelagic limestones attain jointly about 20-25 meters in thickness ( $c f$. Birkenmajer, 1970). Still further south, in the Czertezik Succession of the Czertezik Ridge, the coeval deposits attain only about 10 meters in thickness. The Pieniny Succession (including the southern type of the Branisko Succession), reveals a much larger thickness of the corresponding Jurassic deposits which are composed mostly of radiolarite units but replaced upwards by deep-water carbonates (Fig. 6).

The gradual increase in abundance of microplankton associations in the Western Carpathians basins as observed during the Kimmeridgian and Early Tithonian resulted mostly from development of calcareous microplankton (including Saccocoma rests and calcareous cysts of Dinoflagellata), but also the rise of other plankton groups like radiolar- ians and Globochaete. The change from the planktonic foraminifer microfacies to the Saccocoma microfacies took place already in the late Early Kimmeridgian: it was documented by ammonites in the Czorsztyn Succession as occurring well above the Bimammatum and Planula zones (Myczyński, Wierzbowski, 1994), recognized then as corresponding to the uppermost Oxfordian, but this stratigraphical interval was recently correlated already with the lowermost Kimmeridgian according to the newly ratified GSSP base of the Kimmeridgian Stage (Coe, Wierzbowski, 2021). During the Late Tithonian a marked decrease in the number of Saccocoma to an increase of calpionellids is observed. The latter attained an explosion in their development near the Tithonian/Berrisian boundary (e.g. Reháková, Michalík, 1994). The thickness of the Tithonian pelagic (mostly carbonate) deposits differed markedly, however, between the Pieniny Klippen basins, where it was relatively low, and the Central Western Carpathian basins where it increased markedly toward south. It is interpreted as resulting from Neo-Cimmerian tectonic deformations which caused changes in the sedimentary environments both of eustatic and hydrodynamic nature (Reháková, Michalík, 1994).

According to Grabowski et al. (2008)'s palaeomagnetic data, the tectonic regime of the Czorsztyn Ridge during the Kimmeridgian to Early Berriasian was denoted originally by its position at a significantly large distance from the European Plate, but this successively diminished due to the northward drift of the Czorsztyn Ridge area. It seems to be consistent with the observed "switch from biosiliceous to carbonate sedimentation coincide with warming and increasing aridity of climate" during Late Jurassic in the Western Carpathians area, which could be related to the development of favourable conditions for carbonate sedimentation due to the northward drift of the area (Jach, Reháková, 2019, p. 39).

The following distinct uplift of the Czorsztyn Ridge was generally related to the Neo-Cimmerian movements which attained their acme during the Late Berriasian to Hauterivian in the Walentowa Phase of rifting (Plašienka, 2003, 2012). This phase "ultimately led to the opening of the Magura Ocean on the northern side of the Czorsztyn Ridge" (Plašienka, 2012, p. 613). However, the relation of this new stage of development of the "Magura Ocean" to the earlier one of Callovian-Oxfordian age is not clear, staying the subject of different tectonic interpretation, also in relation to stratigraphical position of the relevant deposits in the Pieniny Klippen Belt (see e.g. Birkenmajer et al., 2008, and references given therein). This problem is beyond the scope of the present study.

Final remarks. Summarizing, the Jurassic facies pattern of the Pieniny Klippen Belt bears a strong contrast between the areas of two ridges (Czorsztyn Ridge corresponding to the Czorsztyn Succession and the Czertezik Ridge corre- 
sponding to the Czertezik Succession) and the intervening slopes to basins (Niedzica to northern type of the Branisko/ to Czertezik-like slope successions in the northern basin versus southern type of the Branisko to the Pieniny Sucession in the southern basin). The contrast was not constant during the history of sedimentation, as there appeared stratigraphical intervals when it was more accentuated (during the Toarcian-?Aalenian for the Czertezik Ridge, and the Bajocian when both ridges were elevated), or less accentuated (especially during the Kimmeridgian and Tithonian). The strong contrast in facies development corresponded to the active tectonic phases, the weaker contrast generally corresponded to episodes of a fairly uniform subsidence. Independently, there existed, however, marked differences between the logs of deposits from the northern Pieniny Klippen basin (Czorsztyn-Niedzica - northern type of the Branisko/ to Czertezik-like slope successions) and the southern Pieniny Klippen basin (Czertezik Succession - southern type of the Branisko to Pieniny Succession), recognized especially in the interval of the uppermost Lower Jurassic to lower part of the Middle Jurassic (Fig. 6). This is because of the different geological history of the two areas.

The subdivision of the Pieniny Klippen Belt into the two discussed areas correlates very well with the postulated megatectonic units - the Subpieniny Nappe and the Pieniny Nappe. It can be additionally assumed that the origin of these two megatectonic units was possibly related to deep tectonic fractures responsible originally for formation of the Czorsztyn Ridge and the Czertezik Ridge, which were successively partly transformed into thrust zones during formation of the Laramian nappes (Figs. 6, 8, 9). It seems highly probable that the Czertezik Succession (Unit) is discontinuously preserved along the base of the main Laramian thrust-zone of the Pieniny Nappe (including Branisko southern type). Because of generally small thickness and mass of the Pieniny Klippen Belt nappes, strong internal folding and brittle fracturing occurred during their transport which resulted in numerous calcite coatings and veins prevailing sometimes over the host rock (Jurewicz, 2005). This could be the reason for the strong transformation of the rocks in wide zones adjoining the thrust sheets, which possibly also together with the activity of hot fluids eliminated locally the organic-walled Dinoflagellate cysts. Such a situation occurred possibly in the central segment of the Pieniny Klippen Belt between the Dunajec Fault Zone (Krościenko Fault Zone) and the Straszny Potok Fault Zone where the deposits of the Lower and Middle Jurassic adjoining the base of the Pieniny Nappe (Fig. 8) are almost completely devoid of organic-walled cysts, whereas in the coeval deposits of the same and other successions in other areas the cysts are recognized commonly (cf. Gedl, 2008; Segit, 2010). A similar situation was encountered in the Maruszyna IG-1
Deep Borehole in the western part of the Pieniny Klippen Belt in Poland (Fig. 1) where the Middle Jurassic deposits of the tectonic wedge at the base of the Jurassic Branisko Unit showed highly degraded dinoflagellate cysts, whereas the deposits placed higher, and lower in the core yielded commonly well-preserved specimens (Gedl in: Birkenmajer, Gedl, 2012).

The presence of ammonitico-rosso type deposits of Toarcian age in the southern Pieniny Klippen basin, both alleged (because of their redeposition) in the area of study, but also preserved as primary deposits well-dated by ammonites (as e.g. in the Transcarpathian Ukraine, see Wierzbowski et al., 2012) yields new data on the activity of the Devín Phase of rifting in that area (cf. Plašienka, 2003). The Toarcian deposits can be easily correlated with the Adnet Formation typical of the Lower Austroalpine and northern Tatric units facing the Penninic (South Penninic, Piemont) Ocean (e.g. Plašienka, 2003, 2012; Gawlick et al., 2009), and generally not recognized so far in the units of the socalled "Middle Penninic position" corresponding to the Oravicum sensu Mahel' (see Plašienka, 2012).

It should be remembered that the original palaeogeographical zone of the Pieniny Klippen Belt is commonly recognized as the Oravicum which commonly includes both the ridge (Czorsztyn) and basinal successions (after Mahel', e.g. Plašienka, 1999, 2012), but sometimes it is also called Pieninicum (e.g. Mišík, Aubrecht, 1994). Although these two terms are usually treated as synonymous (Plašienka, 1999), it is proposed herein to distinguish the Oravicum as corresponding to the Czorsztyn-Niedzica-Branisko (northern type) successions representing together the northern Pieniny Klippen basin (as named herein), from the Pieninicum as corresponding to the Czertezik-Pieniny (including Branisko southern type) successions (southern Pieniny Klippen basin as named herein) because of their dissimilar geological history and tectonic setting (Fig. 6). The problem of subdivision of the original sedimentary area of the Pieniny Klippen Belt into two different zones as suggested above remains, however, only a proposal before additional studies in other areas of the Pieniny Klippen Belt in Slovakia and in Ukraine will be undertaken to confirm the suggestions given.

Acknowledgements. The study was supported by the PGI-NRI statutory funds (Project No. 61.2908.1801.00.0). The admittance to the protected area of the Pieniny National Park was kindly provided by the Director of the Park Michał Sokołowski and Krzysztof Karwowski. Special thanks are also given to several our colleagues who helped in collecting specimens from the area at Pieniński Creek during studies in common in the past on the occasion of other projects: Roman Aubrecht, Jolanta Iwańczuk, Bronisław A. Matyja and Jano Schlögl. This paper corresponds to the IGCP-710 
Project of UNESCO. The authors are grateful to Renata Jach and Dušan Plašienka, the editorial referees, for their valuable comments and discussion.

\section{REFERENCES}

ARABAS A., SCHLÖGL J., MEISTER CH., 2017 - Early Jurassic carbon and oxygen isotope records and seawater temperature variations: Insights from marine carbonate and belemnite rostra (Pieniny Klippen Belt, Carpathians). Palaeogeography, Palaeoclimatology, Palaeoecology, 485: 119-135.

AUBRECHT R., 1997 - Indications of the Middle Jurassic emergence in the Czorsztyn Unit (Pieniny Klippen Belt, Western Carpathians). Geologica Carpathica, 48, 2: 71-84.

AUBRECHT R., 2001 - New occurrences of the Krasin Breccia (Pieniny Klippen Belt, West Carpathians): indication of Middle Jurassic synsedimentary tectonics. Acta Geologica Universitatis Comenianae, 56, 3: 35-56.

AUBRECHT R., SÝKORA M., 1998 - Middle Jurassic crinoidal complex at Hatné-Hrádok locality (Czorsztyn Unit, Pieniny Klippen Belt, western Slovakia). Mineralia Slovaca, 30, 2: $157-166$.

AUBRECHT R., TÚNYI I., 2001 - Original orientation of neptunian dykes in the Pieniny Klippen Belt (Western Carpathians): the first results. Contributions to Geophysics and Geodesy, 31, 3: 557-578.

AUBRECHT R., MIŠÍK M., SÝKORA M., 1997 - Jurassic synryft sedimentation on the Czorsztyn Swell of the Pieniny Klippen Belt in Western Slovakia. In: Alpine evolution of the Western Carpathians and related areas, International Conference held on occasion of Centennial of Dmitrij Andrusov, Bratislava, Slovakia 11-14 September, 1997 (Eds D. Plašienka et al.): 5364. Geological Survey of Slovak Republic, Bratislava.

AUBRECHT R., SCHLÖGL J., KROBICKI M., WIERZBOWSKI A., 2017 - Czorsztyn Ridge was not uniform: new data from the Ukrainian part of the Pieniny Klippen Belt (Eastern Carpathians). Acta Geologica Slovaca, 9, 2: 115-135.

BARSKI M., MATYJA B.A., SEGIT T., WIERZBOWSKI A., 2012 - Early to Late Bajocian age of the „black flysch” (Szlachtowa Fm.) deposits: implications for the history and geological structure of the Pieniny Klippen Belt, Carpathians. Geological Quarterly, 56, 3: 391-410.

BĄK M., CHODACKA S., BĄK K., OKOŃSKI S., 2018 - New data on the age and stratigraphic relationships of the Czajakowa Radiolarite Formation in the Pieniny Klippen Belt (Carpathians) based on the radiolarian biostratigraphy in the stratotype section. Acta Geologica Polonica, 68, 1: 1-20.

BIRKENMAJER K., 1953 - Preliminary revision of the stratigraphy of the Pieniny Klippen Belt series in Poland. Bulletin de l'Academie Polonaise des Sciences, Cl.III, 1, 6: 271-274.

BIRKENMAJER K., 1959 - A new klippen series in the Pieniny Mts., Carpathians - the Czertezik Series. Acta Geologica Polonica, 9, 4: 499-515 (in Polish with English summary).

BIRKENMAJER K., 1965 - Zarys budowy geologicznej pienińskiego pasa skałkowego Polski. Rocznik Polskiego Towarzystwa Geologicznego, 35: 327-356.
BIRKENMAJER K., 1970 - Pre-Eocene fold structures in the Pieniny Klippen Belt (Carpathians) of Poland. Studia Geologica Polonica, 31: 1-77 (in Polish with English summary).

BIRKENMAJER K., 1977 - Jurassic and Cretaceous lithostratigraphic units of the Pieniny Klippen Belt, Carpathians, Poland. Studia Geologica Polonica, 45: 1-159.

BIRKENMAJER K., 1986 - Stages of structural evolution of the Pieniny Klippen Belt, Carpathians. Studia Geologica Polonica, 88: 7-32.

BIRKENMAJER K., 1988 - Exotic Andrusov Ridge: its role in plate-tectonic evolution of the West Carpathian Foldbelt. Studia Geologica Polonica, 91: 7-37.

BIRKENMAJER K., 2007 - The Czertezik Succession in the Pieniny National Park (Pieniny Klippen Belt, West Carpathians): Stratigraphy, tectonics and palaeogeography. Studia Geologica Polonica, 127: 7-50.

BIRKENMAJER K., 2008 - The Szopka Limestone Formation a new lithostratigraphic name for Upper Liassic beds of the Pieniny and Branisko successions, Pieniny Klippen Belt (Western Carpathians). Studia Geologica Polonica, 131: 229-235.

BIRKENMAJER K., 2009 - The Branisko Succession (JurassicCretaceous) in the Czorsztyn Range, Pieniny National Park (Pieniny Klippen Belt, West Carpathians, Poland): description of selected field sections. Studia Geologica Polonica, 132: 71-90.

BIRKENMAJER K., 2017 - Geology of the Pieniny Mountains, West Carpathians, Poland. Monografie Pienińskie, 3: 1-66 (in Polish with English summary).

BIRKENMAJER K., GEDL P., 2012 - Jurassic and Cretaceous strata in the Maruszyna IG-1 Deep Borehole (Pieniny Klippen Belt, Carpathians, Poland): Lithostratigraphy, dinoflagellate cyst biostratigraphy, tectonics. Studia Geologica Polonica, 135: 7-54.

BIRKENMAJER K., MYCZYŃSKI R., 1994 - Pliensbachian (Early Jurassic) fauna from the Pieniny Klippen Belt, Carpathians, Poland: its stratigraphic and palaeogeographic position. Bulletin of the Polish Academy of Sciences, Earth Sciences, 42, 4: 223-245.

BIRKENMAJER K., GEDL P., MYCZYŃSKI R., TYSZKA J., 2008 - „Cretaceous black flysch” in the Pieniny Klippen Belt, West Carpathians: a case of geological misinterpretation. Cretaceous Research, 29: 535-549.

BORECKA A., DANEL W., KROBICKI M., WIERZBOWSKI A., 2013 - Pieniński Park Narodowy. Mapa geologiczno-turystyczna $1: 25000$. Państwowy Instytut Geologiczny - Państwowy Instytut Badawczy, Warszawa.

COE A., WIERZBOWSKI A., 2021 - The Kimmeridgian (Upper Jurassic) Global Stratotype Section and Point is defined and placed in Scotland UK. IUGS News: 15.03.2021.

CSONTOS L., VÖRÖS A., 2004 - Mesozoic plate tectonic reconstruction of the Carpathian region. Palaeogeography, Palaeoclimatology, Palaeoecology, 210: 1-56.

DOMMERGUES J.L., MEISTER CH., MOUTERDE R., 1997 Pliensbachian. In: Biostratigraphie du Jurassique oust-européen et méditerranéen: zonations paralléles et distribution des invertébrés et microfossiles (Coord. E. Cariou, P. Hanzpergue). Bulletin du Centre de Recherche Elf Exploration et Production, 17: 114-119. 
GAWLICK H.J., MISSONI S., SCHLAGINTWEIT F., SUZUKI H., FRISCH W., KRYSTYN L., BLAU J., LEIN R., 2009 Jurassic tectonostratigraphy of the Austroalpine domain. Journal of Alpine Geology, 50: 1-152.

GEDL P., 2008 - Organic-walled dinoflagellate cyst stratigraphy of dark Middle Jurassic marine deposits of the Pieniny Klippen Belt, Western Carpathians. Studia Geologica Polonica, 131: 7-227.

GINAŁ E., 1998 - Górna jura i dolna kreda w okolicach wsi Sromowce Wyżne (Pieniński Pas Skałkowy) [Unpubl. M.Sc. Thesis]. Faculty of Geology, University of Warsaw.

GRABOWSKI J., KROBICKI M., SOBIEŃ K., 2008 - New palaeomagnetic results from the Polish part of the Pieniny Klippen Belt, Carpathians - evidence for the palaeogeographic position of the Czorsztyn Ridge in the Mesozoic. Geological Quarterly, 52, 1: 31-44.

GRADZIŃSKI M., TYSZKA J., UCHMAN A., JACH R., 2004 Large microbial-foraminiferal oncoids from condensed LowerMiddle Jurassic deposits: a case study from the Tatra Mountains, Poland. Palaeogeography, Palaeoclimatology, Palaeoecology, 213: $133-151$.

GRADZIŃSKI M., JACH R., MYCZYŃSKI R., TYSZKA J., UCHMAN A., 2006 - Huciański Klin Crest: Eastern part - late Early Toarcian-Aalenian red limestones and marlstones. In: Jurassic of Poland and adjacent Slovakian Carpathians (Eds A. Wierzbowski et al.): 110-111. Field trip guidebook. $7^{\text {th }}$ International Congress on the Jurassic System, 6-18 September 2006, Kraków, Poland. Polish Geological Institute, Warszawa.

HAŠKO J., 1978 - Oravská séria - nová séria bradlového pásma Západných Karpát. Geologické Práce, Správy, 70: 115-121.

HEJNAR J., 2019 - Biostratigraphy, lithostratigraphy and chemostratigraphy of Late Jurassic to Early Cretaceous pelagic facies between Czorsztyn, Zamkowa Góra and Červený Kláštor (Pieniny Klippen Belt). In: XIVth Jurassica Conference \& Workshop of the ICS Berriasian Group, Bratislava, 2019 (Eds K. Feteke et al.). Field trip guide and Abstracts book, 118-119.

HESSELBO S.P., OGG J.G., RUHL M., HINNOV L.A., HUANG C.J., 2020 - The Jurassic Period. In: Geological Time Scale: 955-1021. Elsevier B.V.

HORWITZ L., 1937a - Fauna i wiek warstw posidoniowych w Pienińskim Pasie Skałkowym. A. Część ogólna [Le faune et l'âge des couches à Posidonomyes (zone Piénine des Klippes, Karpates Polonaises), A. partie génerale]. Sprawozdanie Państwowego Instytutu Geologicznego, 8, 4: 69-127 (in Polish and French).

HORWITZ L., 1937b - Fauna i wiek warstw posidoniowych w Pienińskim Pasie Skałkowym. B. część szczegółowa [Le faune et l'âge des couches à Posidonomyes (zone Piénine des Klippes, Karpates Polonaises), B partie detailée]. Sprawozdanie Państwowego Instytutu Geologicznego, 9, 1: 166-274 (in Polish and French).

HORWITZ L., 1963 - Geological structure of the Pieniny Mts., Carpathians (posthumous edition based on manuscripts compiled by K. Birkenmajer). Prace Instytutu Geologicznego, 38 : 1-152 (in Polish).

HUDSON W., HART M.B., SIDORCZUK M., WIERZBOWSKI A., 2005 - Jurassic planktonic foraminifera from Pieniny Klippen Belt and their taxonomic and phylogenetic importance
(Carpathians, southern Poland). Tomy Jurajskie (Volumina Jurassica), 3: 1-10.

JACH R., 2003 - Bositra limestones - a step towards radiolarites: case study from the Tatra Mountains. Annales Societatis Geologorum Poloniae, 77: 161-170.

JACH R., DUDEK T., 2005 - Origin of a Toarcian manganese carbonate/silicate deposit from the Krížna unit, Tatra Mountains, Poland. Chemical Geology, 224: 136-152.

JACH R., REHÁKOVÁ D., 2019 - Middle to Late Jurassic carbonate-biosiliceous sedimentation and palaeoenvironment in the Tethyan Fatricum Domain, Križna Nappe, Tatra Mountains, Western Carpathians. Annales Societatis Geologorum Poloniae, 89, 1: 1-46.

JUREWICZ E., 2005 - Geodynamic evolution of the Tatra Mts. and the Pieniny Klippen Belt (Western Carpathians): problems and comments. Acta Geologica Polonica, 55, 3: 295-338.

JUREWICZ E., 2018 - The Šariš Transitional Zone, revealing interactions between Pieniny Klippen Belt, Outer Carpathians and European platform. Swiss Journal of Geosciences, 111 (5824). DOI:10.1007/s00015-017-0297-9.

JUREWICZ E., SEGIT T., 2018 - The tectonics and stratigraphy of the transitional zone between the Pieniny Klippen Belt and Magura Nappe (Szczawnica area, Poland). Geology, Geophysics and Environment, 44, 1.

KASIŃSKI J.R., PIEŃKOWSKI G., PISERA A., 1981 - Lithologic-microfacies characteristics of the Branisko and Czorsztyn successions along the road from Krośnica to Kąty, Pieniny Klippen Belt, Carpathians. Studia Geologica Polonica, 70: 73-94 (in Polish with English summary).

KROBICKI M., 2009 - Bajocian synsedimentary tectonics and its significance in Jurassic evolution of the Pieniny Klippen Belt. Geologia (Kwartalnik AGH), 35, 3/1: 65-78 (in Polish with English summary).

KROBICKI M., 2018 - Duration of the Czorsztyn Ridge uplift (Pieniny Klippen Belt, Carpathians) during the Early Bajocian time. In: Environmental, Structural and Stratigraphical Evolution of the Western Carpathians, Abstract Book, $11^{\text {th }}$ ESSEWECA Conference, 29 $9^{\text {th }}-30^{\text {th }}$ November 2018, Bratislava, Slovakia (Eds M. Šujan et al.): 50-51.

KROBICKI M., UCHMAN A., 2006 - Ichnofabrics of the Middle Jurassic manganeouse radiolarites from the Branisko and Pieniny successions of the Pieniny Klippen Belt and their palaeoenvironmental implications. Volumina Jurassica, 4: 119.

KROBICKI M., WIERZBOWSKI A., 2004 - Stratigraphic position of the Bajocian crinoidal limestones and their palaeogeographic significance in evolution of the Pieniny Klippen Basin. Tomy Jurajskie (Volumina Jurassica), 2: 69-82 (in Polish with English summary).

KROBICKI M., WIERZBOWSKI A., 2009 - Middle Jurassic nodular limestones of the Czertezik Succession of the Pieniny Klippen Basin - facts and controversies. Przeglad Geologiczny, 57: 600-606 (in Polish with English summary).

KSIĄŻKIEWICZ M., 1972 - Karpaty. Budowa geologiczna Polski, t. IV, Tektonika, 3. Wydawnictwa Geologiczne, Warszawa.

LEWANDOWSKI M., KROBICKI M., MATYJA B.A., WIERZBOWSKI A., 2005 - Palaeogeographic evolution of the Pieniny Klippen Basin using stratigraphic and palaeomagnetic data from the Veliky Kamenets section (Carpathians, Uk- 
raine). Palaeogeography, Palaeoclimatology, Palaeoecology, 216: $53-72$.

LEWANDOWSKI M., AUBRECHT R., KROBICKI M., MATYJA B.A., REHÁKOVÁ D., SCHLÖGL J., SIDORCZUK M., WIERZBOWSKI A., 2006 - Palaeomagnetism of the Pieniny Klippen Belt (Carpathians): Evidence for low-latitude origin and palaeogeographic dispersion of the Upper Jurassic carbonates. Volumina Jurassica, 4: 56-58.

MATYJA B.A., 2015 - Jurajska ewolucja północnego obrzeża Tetys. In: Ekstensja i inwersja powaryscyjskich basenów sedymentacyjnych. 84 Zjazd Naukowy Polskiego Towarzystwa Geologicznego, Chęciny 9-11.09.2015 (Ed. S. Skompski). Państwowy Instytut Geologiczny - PIB, Warszawa.

MATYJA B.A., WIERZBOWSKI A., 2006 - The oceanic „Metis Geotectonic Event" (Callovian/Oxfordian) and its implications for the peri-Tethyan area of Poland. Tomy Jurajskie (Volumina Jurassica), 4: 60-61.

MIŠÍK M., 1994 - The Czorsztyn Submarine Ridge (Jurassic-Lower Cretaceous, Pieniny Klippen Belt): An example of a pelagic swell. Mitteilungen der Österreichischen Geologischen Gesellschaft, 86; 133-140.

MIŠÍK M., AUBRECHT R., 1994 - The source of rock fragments in the Jurassic crinoidal limestones of the Pieninicum (Klippen Belt, Western Carpathians). Geologica Carpathica, 45, 3: 159170.

MIŠÍK M., SÝKORA M., AUBRECHT R., 1994 - Middle Jurassic scarp breccias with cleft filled by Oxfordian and ValanginianHauterivian sediments, Krasin near Dolná Súča (Pieniny Klippen Belt). Geologica Carpathica, 45, 6: 343-356.

MYCZYŃSKI R., 1973 - Middle Jurassic stratigraphy of the Branisko succession in the vicinity of Czorsztyn (Pieniny Klippen Belt, Carpathians). Studia Geologica Polonica, 42: 1-122 (in Polish with English summary).

MYCZYŃSKI R., 2004 - Toarcian, Aalenian and Early Bajocian (Jurassic) ammonite faunas and biostratigraphy in the Pieniny Klippen Belt and the Tatra Mts., West Carpathians. Studia Geologica Polonica, 123: 7-131.

MYCZYŃSKI R., WIERZBOWSKI A., 1994 - The ammonite succession in the Callovian, Oxfordian and Kimmeridgian of the Czorsztyn Limestone Formation, at Halka Klippe, Pieniny Klippen Belt, Carpathians. Bulletin of the Polish Academy of Sciences, Earth Sciences, 42, 3: 155-164.

OBERMAJER M., 1986 - Mikrofacje i wiek formacji wapienia pienińskiego płaszczowiny pienińskiej. In: Przewodnik 57. Zjazdu Polskiego Towarzystwa Geologicznego, Pieniński Pas Skałkowy, wycieczki A i B (Ed. K. Birkenmajer): 100-102. Kraków, 1986.

OBERMAJER M., 1987 - Preliminary micropalaeontological study of the Pieniny Limestone Formation (Tithonian-Barremian) in the Pieniny Klippen Belt, Carpathians (Poland). Studia Geologica Polonica, 92: 41-54 (in Polish with English summary).

OŽVOLDOVÁ L., JABLONSKÝ J., FRANTOVÁ L., 2000 - Upper Jurassic radiolarites of the Czertezik Succession and comparision with the Kysuca Succession in the east-Slovak part of the Pieniny Klippen Belt (Western Carpathians, Slovakia). Geologica Carpathica, 51, 2: 109-119.

PLAŠIENKA D., 1999 - Tektonochronolólogia a paleotektonický model jursko-kriedového vývoja centralnych Zapádných Kar- pát: 1-125. Veda: Vydavatel'stvo Slovenskej Akadémie Vied. Bratislava.

PLAŠIENKA D., 2003 - Dynamics of Mesozoic pre-orogenic rifting in the Western Carpathians. Mitteilungen der Österreichischen Geologischen Gesellschaft, 94, 2001: 79-98.

PLAŠIENKA D., 2012 - Jurassic syn-rift and Cretaceous syn-orogenic, coarse-grained deposits related to opening and closure of the Vahic (South Penninic) Ocean in the Western Carpathians an overview. Geological Quarterly, 56, 4: 601-628.

PLAŠIENKA D., 2018 - Continuity and episodicity in the early Alpine tectonic evolution of the Western Carpathians: How large-scale processes are expressed by the orogenic architecture and rock record data. Tectonics, 37. https://doi. org./10.1029/2017TC004779.

PLAŠIENKA D., 2019 - Linkage of the Manin and Klape units with the Pieniny Klippen Belt and Central Western Carpathians: balancing and ambiguity. Geologica Carpathica, 70, 1: 35-61.

PLAŠIENKA D., MIKUŠ V., 2010 - Geologická stavba pieninského a šariškého úseku bradlového pásma medzi Litmanovou a Drienicou na východnom Slovensku. Mineralia Slovaca, 42: $155-178$.

REHÁKOVÁ D., MICHALÍK J., 1994 - Abundance and distribution of Late Jurassic-Early Cretaceous microplankton in Western Carpathians. Geobios, 27, 2: 135-156.

REHÁKOVÁ D., MATYJA B.A., WIERZBOWSKI A., SCHLÖGL J., KROBICKI M., BARSKI M., 2011 - Stratigraphy and microfacies of the Jurassic and lowermost Cretaceous of the Veliky Kamenets section (Pieniny Klippen Belt, Carpathians, Western Ukraine). Volumina Jurassica, 9: 61-104.

SCHEIBNER E., 1964 - Contribution to the knowledge of the Murchisonae Beds in the Klippen Belt of West Carpathians in Slovakia. Geologicky Sbornik, 15: 27-55.

SCHLÖGL J., AUBRECHT R., 2009 - Lithostratigraphy of Pieniny Klippen Belt units and per-Klippen units. Geologia (Kwartalnik AGH.), 35, 3/1: 125-131.

SCHLÖGL J., AUBRECHT R., TOMAŠOVÝCH A., 2000 - The first find of the Orava Unit in the Púchov section of the Pieniny Klippen Belt (Western Slovakia). Mineralia Slovaca, 32: 45-54.

SCHLÖGL J., TOMAŠOVÝCH A., STOLARSKI J., RAKÚS M., 2001 - Migration of the early Middle Oxfordian Boreal ammonites documented from the neptunian dyke deposits in the Pieniny Klippen Belt, Western Carpathians (Slovakia). International Conference Paleobiogeography \& Paleoecology, May 31 - June 2, 2001, Piacenza \& Castell'Arquato, Italy. Conference volume: 191-192.

SCHLÖGL J., RAKÚS M., KROBICKI M., MATYJA B.A., WIERZBOWSKI A., AUBRECHT R., SITÁR V., JÓZSA Š., 2004 - Beňatina Klippe - lithostratigraphy, palaeontology of the Jurassic and Lower Cretaceous deposits (Pieniny Klippen Belt, Western Carpathians, Slovakia). Slovak Geological Magazine, 10, 4: 241-262.

SCHLÖGL J., RAKÚS M., AUBRECHT R., 2006 - Stop B3.2 Podbiel - Červena Skala. In: Jurassic of Poland and adjacent Slovakian Carpathians (Eds A. Wierzbowski et al.): 83-85. Field trip guidebook. $7^{\text {th }}$ International Congress on the Jurassic System, 6-18 September 2006, Kraków, Poland. Polish Geological Institute, Warszawa. 
SCHLÖGL J., MANGOLD CH., TOMAŠOVÝCH A., GOLEJ M., 2009 - Early and Middle Callovian ammonites from the Pieniny Klippen Belt (Western Carpathians) in hiatal successions: Unique biostratigraphic evidence from sediment-filled fissure deposits. Neues Jahrbuch für Geologie und Paläontologie Abhandlungen, 252, 1: 55-79.

SEGIT T., 2010 - Stratigraphy, facies development and paleoenvironment of the Aalenian and Lower Bajocian deposits of the Pieniny Klippen Basin in the sections from Poland and Slovakia [Unpubl. Ph.D. Thesis]. Faculty of Geology, University of Warsaw: 1-152 (in Polish).

SEGIT T., MATYJA B.A., WIERZBOWSKI A., 2015 - The Middle Jurassic succession in the central sector of the Pieniny Klippen Belt (Sprzycne Creek): Implications for the timing of the Czorsztyn Ridge development. Geologica Carpathica, 66, 4: 285-302.

SIDORCZUK M., 2005 - Middle Jurassic ammonitico rosso deposits in the northwestern part of the Pieniny Klippen Belt in Poland and their palaeogeographic importance: a case study from Stankowa Skała and "Wapiennik" quarry in Szaflary. Annales Societatis Geologorum Poloniae, 75: 273-285.

SIDORCZUK M., NEJBERT K., 2008 - Genesis of ferromanganese crusts in Jurassic pelagic limestones at Stankowa Skała, Pieniny Klippen Belt, Poland: sedimentological and petrological approach. Volumina Jurassica, 6: 75-85.

SIDORCZUK M., LEWANDOWSKI M., BEŁKA Z., 2009 - Riftrelated environmental change in the northern Tethys based on $\mathrm{Nd}$ and $\mathrm{Sr}$ isotopes in the Middle and Upper Jurassic carbonates of the Pieniny Klippen Belt. Geologia (Kwartalnik $A G H)$, 35, 3/1: 97-98.

TYSZKA J., 1994 - Paleoenvironmental implications from ichnological and microfaunal analysis of Bajocian spotty carbonates, Pieniny Klippen Belt, Polish Carpathians. Palaios, 9; 175-187.

TYSZKA J., 1995 - Flaki Limestone Formation: 94-108. In: MidJurassic palaeoenvironments and benthic communities in the Klippen and Magura basins, Pieniny Klippen Belt, Poland [Unpubl. Ph.D. Thesis]. Institute of Geological Sciences, Polish Academy of Sciences, Kraków.

TYSZKA J., KAMINSKI M.A., 1995 - Factors controlling the distribution of agglutinated foraminifera in Aalenian-Bajocian dysoxic facies (Pieniny Klippen Belt, Poland). In: Proceedings of the Fourth International Workshop on Agglutinated Foraminifera, Kraków, Poland, September 12-19 (Eds M.A. Kaminski et al.). Grzybowski Foundation Special Publication, 3: 271-291.

UHLIG V., 1881 - Ueber die Fauna des rothen Kellowaykalks der penninische Klippe Babierzówka bei Neumarkt in West-Galizien. Jahrbuch der kaiserlich-königlischen geologische Reichsanstalt, 31, 3: 383-422.

UHLIG V., 1907 - Über die Tektonik der Karpathen. Sitzungberichte der Kaiserischen Akademie der Wissenschaften, matemat.naturwischenschaft Klasse, 116, 1: 871-911.

WIERZBOWSKI A., JAWORSKA M., KROBICKI M., 1999 - Jurassic (Upper Bajocian - lowest Oxfordian) ammonitico rosso facies in the Pieniny Klippen Belt, Carpathians: its fauna, age, microfacies and sedimentary environment. Studia Geologica Polonica, 115: 7-74.

WIERZBOWSKI A., AUBRECHT R., KROBICKI M., MATYJA B.A., SCHLÖGL J., 2004 - Stratigraphy and palaeogeographic position of the Jurassic Czertezik Succession, Pieniny Klippen Belt (Western Carpathians) of Poland and Eastern Slovakia. Annales Societatis Geologorum Poloniae, 74, 3: 237-256.

WIERZBOWSKI A., SCHLÖGL J., AUBRECHT R., KROBICKI M., 2005 - Rediscovery of the classic locality of Callovian in Babiarzowa Klippe (Pieniny Klippen Belt, Poland). Tomy Jurajskie (Volumina Jurassica), 3: 11-14.

WIERZBOWSKI A., KROBICKI M., MUSZYŃSKI M., 2009 Jurassic deposits of the Czertezik Succession of the Zamkowa Mt. (Trzy Korony massif) in the Pieniny Mts. Geologia (Kwartalnik $A G H$ ), 35, 3/1: 107-113 (in Polish).

WIERZBOWSKI A., KROBICKI M., MATYJA B.A., 2012 - The stratigraphy and palaeogeographic position of the Jurassic successions of the Priborzhavske-Perechin Zone in the Pieniny Klippen Belt in the Transcarpathian Ukraine. Volumina Jurassica, 10: 25-60.

WIERZBOWSKI H., WIERZBOWSKI A., IWAŃCZUK J., SEGIT T., 2019 - New data on the Lower and Middle Jurassic transitional beds of the Czertezik Succession, Pieniny Klippen Belt, Poland. In: XIVth Jurassica Conference \& Workshop of the ICS Berriasian Group, Bratislava, 2019 (Eds K. Feteke et al.). Field trip guide and Abstracts book: 184-185. 


\section{DESCRIPTION OF LIHOSTRATIGRAPHIC UNIT}

\section{DURSZTYN LIMESTONE FORMATION (BIRKENMAJER, 1977)}

\section{Zamkowa Góra Bed (herein established)}

Name: After Zamkowa Góra Mt. in Trzy Korony Massif in the main Pieniny Range of the Pieniny Klippen Belt in Poland (Polish name: warstwa z Zamkowej Góry) (Figs. 2, $4,6)$.

Type section: Zamkowa Góra Mt. at the turist trail (Wierzbowski et al., 2009, figs. 1, 2), in the Pieniny National Park.

Thickness: About $0.5-0.8 \mathrm{~m}$ in the Zamkowa Góra section.

Lithology: Micritic limestones with common belemnites containing radiolarians and planktonic foraminifer tests; nu- merous detrital quartz grains, clasts of crinoidal limestones and small grains/aggregates possibly of glaucony, but also Fe-chlorites, also fragments of ferruginous encrustations, especially common in the lowermost and uppermost parts of bed (Pl. 4: A-D).

Boundaries: Lower and upper boundaries sharp of the discontinuity nature.

Geological age: Near the Callovian/Oxfordian boundary; the bed is distinguished at the base of the Dursztyn Limestone Fm., directly above the nodular limestones of the Niedzica Limestone Fm., in the Zamkowa Góra section of the typical area of occurrence of the Czertezik Succession.

Distribution: Czertezik Succession, not known except the type section at Zamkowa Góra Mt.

Equivalents: In part possibly equivalent of the Czajakowa Radiolarite Fm., and the Czorsztyn Limestone Fm. 


\section{PLATE 1}

\section{Microscopic images of thin sections of the Lower and Middle Jurassic rocks of Wielka Pustelnica Mt.}

A. Spotty limestone microfacies - spiculite wackestone (Szopka Limestone Fm.; polarized light)

B. Shining pyrite framboids within a dark zone of spotty limestones of the Szopka Limestone Fm. (reflected light)

C, D. Lowermost grey crinoidal limestones of the Smolegowa Limestone Fm. composed of crinoid ossicles, quartz grains ferruginous crust debris (C), visible in polarized light and shining pyrite grains (D) visible in reflected light

E. A spiculite wackestone grain similar to spotty limestones from the lower part of crinoidal limestones of the Smolegowa Limestone Fm. (polarized light)

F. Two grains of spiculite wackestone similar to spotty limestones and one heavily recrystallized grain of micritic limestone from the lower part of crinoidal limestones of the Smolegowa Limestone Fm. (polarized light) 

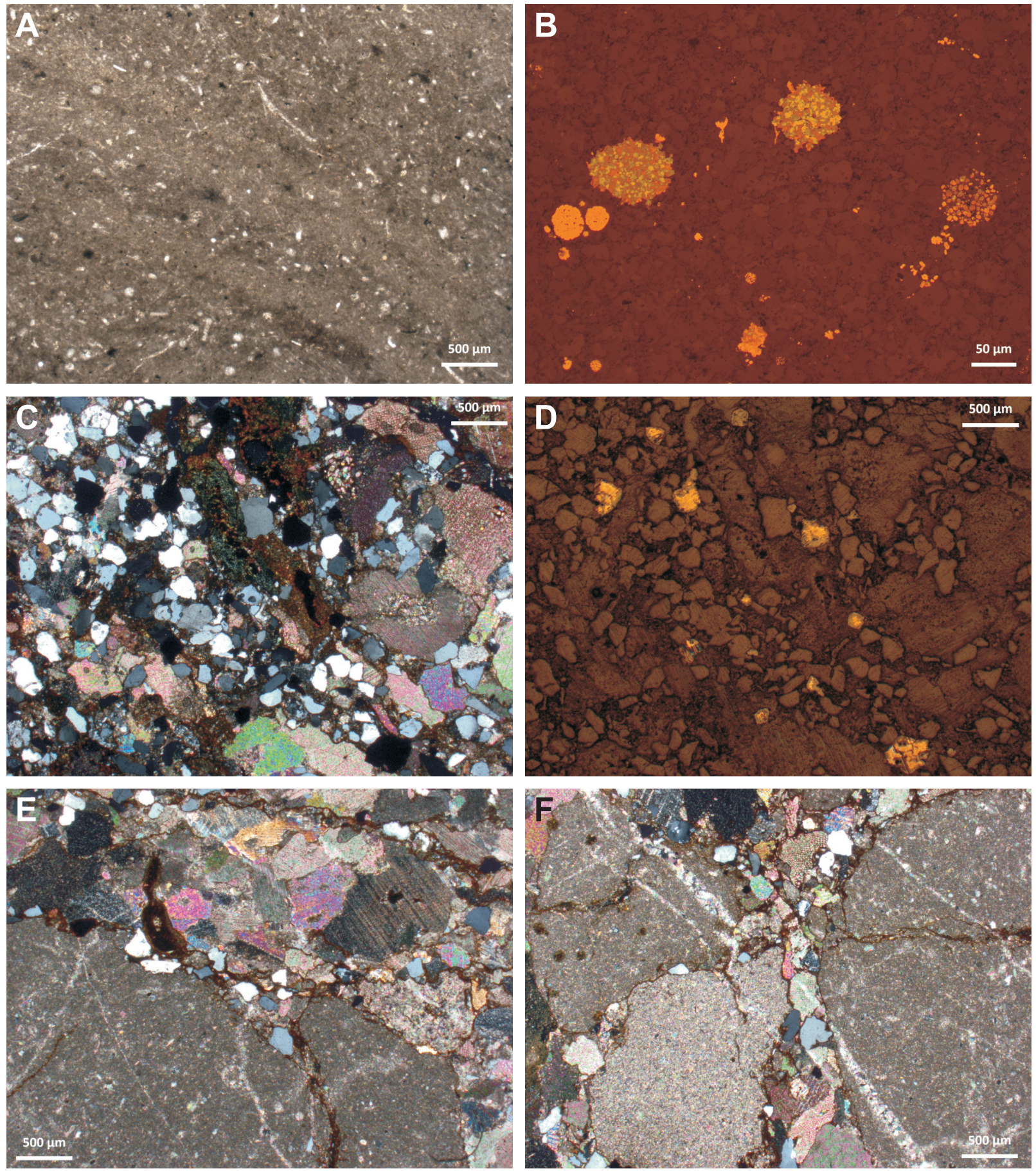

Andrzej WIERZBOWSKI et al. - Jurassic evolution and the structure of the central part of the Pieniny Klippen Belt (Carpathians) in Poland - new insight from the Czertezik Succession type area 


\section{PLATE 2}

\section{Microscopic images of thin sections of Middle Jurassic rocks containing the clasts of Toarcian and Aalenian deposits of Wielka Pustelnica Mt. (continued)}
A, B. A hematite grain from the lower part of crinoidal limestones of the Smolegowa Limestone Fm., which is dark (A) in polarized light and shinning (B) in reflected light
C, D. Lowermost, dark grey part of crinoidal limestones of the Smolegowa Limestone Fm. composed of crinoid ossicles, yellow-grenish fragments of ferruginous crusts, dark phosphorites and quartz grains (polarized light)
E. Fragment of quartz sandstone and quartz grains from the lower part of crinoidal limestones of the Smolegowa Limestone Fm. (polarized, transmitted light)
F. A recrystallized organodetrital wackestone grain similar to Lower Jurassic spotty limestones from the upper part of crinoidal limestones of the Smolegowa Limestone Fm. (bed 18 of Wierzbowski A. et al., 2004; polarized light) 

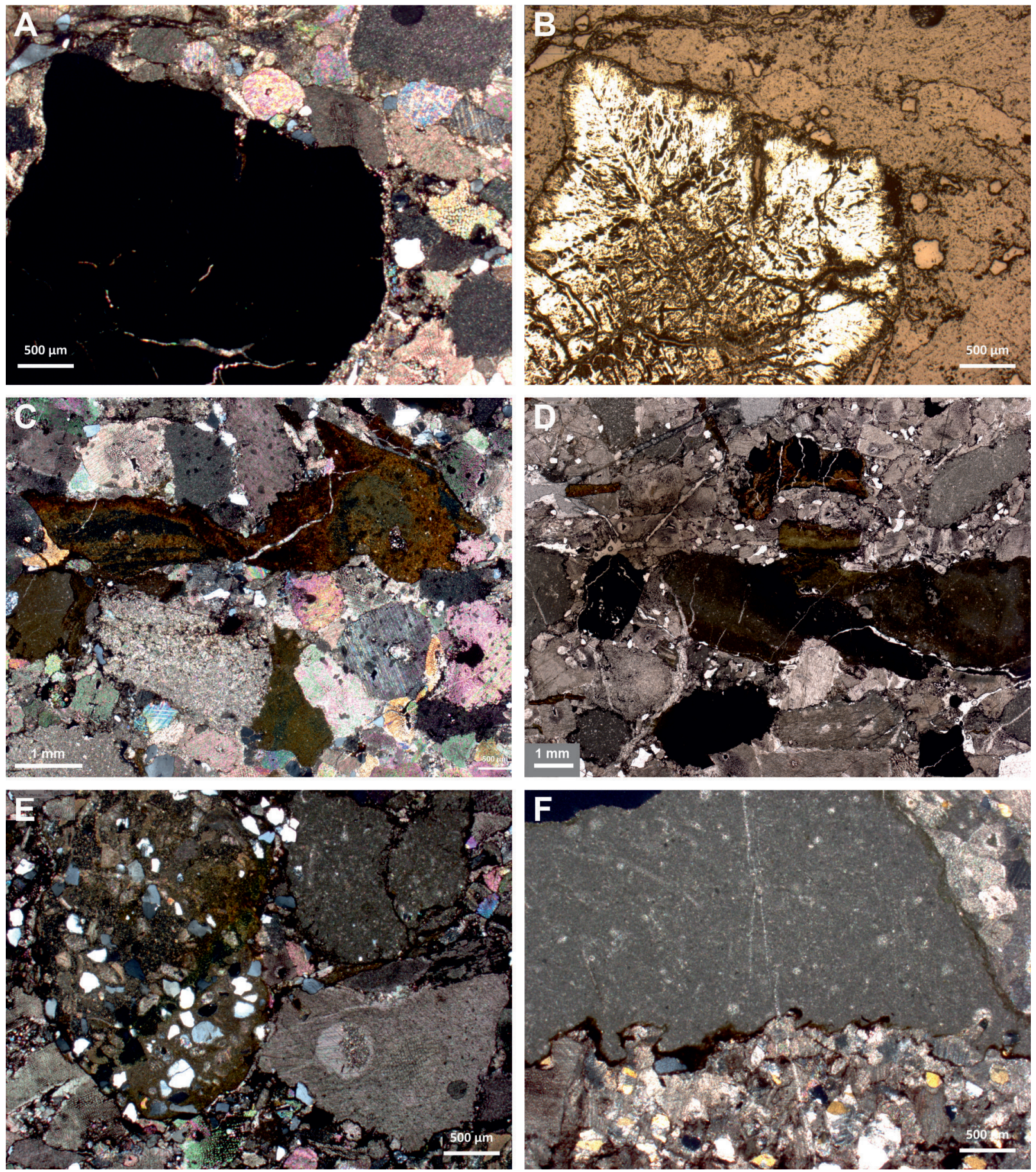

Andrzej WIERZBOWSKI et al. - Jurassic evolution and the structure of the central part of the Pieniny Klippen Belt (Carpathians) in Poland - new insight from the Czertezik Succession type area 


\section{PLATE 3}

Back-scattered electron (BSE) images of the Toarcian clasts of the lower part of Middle Jurassic crinoidal limestones of the Smolegowa Limestone Fm. from Wielka Pustelnica Mt.

A. Irregular hematite-apatite grain associated with small chlorite aggregates

B. Microgranular texture of a large chlorite clast

Abbreviations: apatite (ap), calcite (cal), chlorite (chl), hematite (hem) and quartz (qtz) 

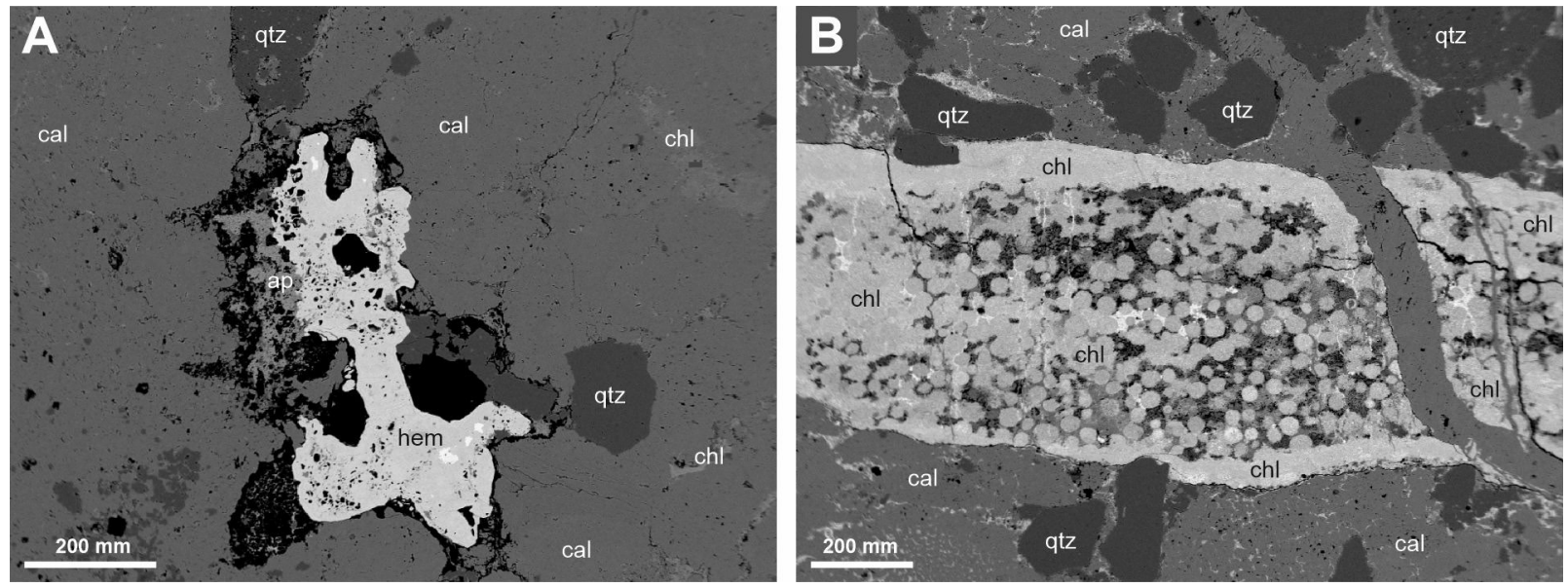


\section{PLATE 4}

Microscopic images of thin sections of the Zamkowa Góra Bed, Dursztyn Limestone Fm. of Zamkowa Góra Mt.

A. Detrital grains of quartz as well as glaucony and chlorite grains in micritic limestone (lowermost part of bed), normal light

B, C. Detrital grains of quartz and glaucony/chlorite in large fragment of ferruginous encrustation in radiolarian wackestone ( $0.4 \mathrm{~m}$ above base of bed), normal and polarized light

D. Glaucony-chlorite aggregates overgrown by calcite veins in radiolarian-planktonic foraminifer packstone with some larger echinoderm bioclasts and sparse quartz grains (uppermost part of bed) 

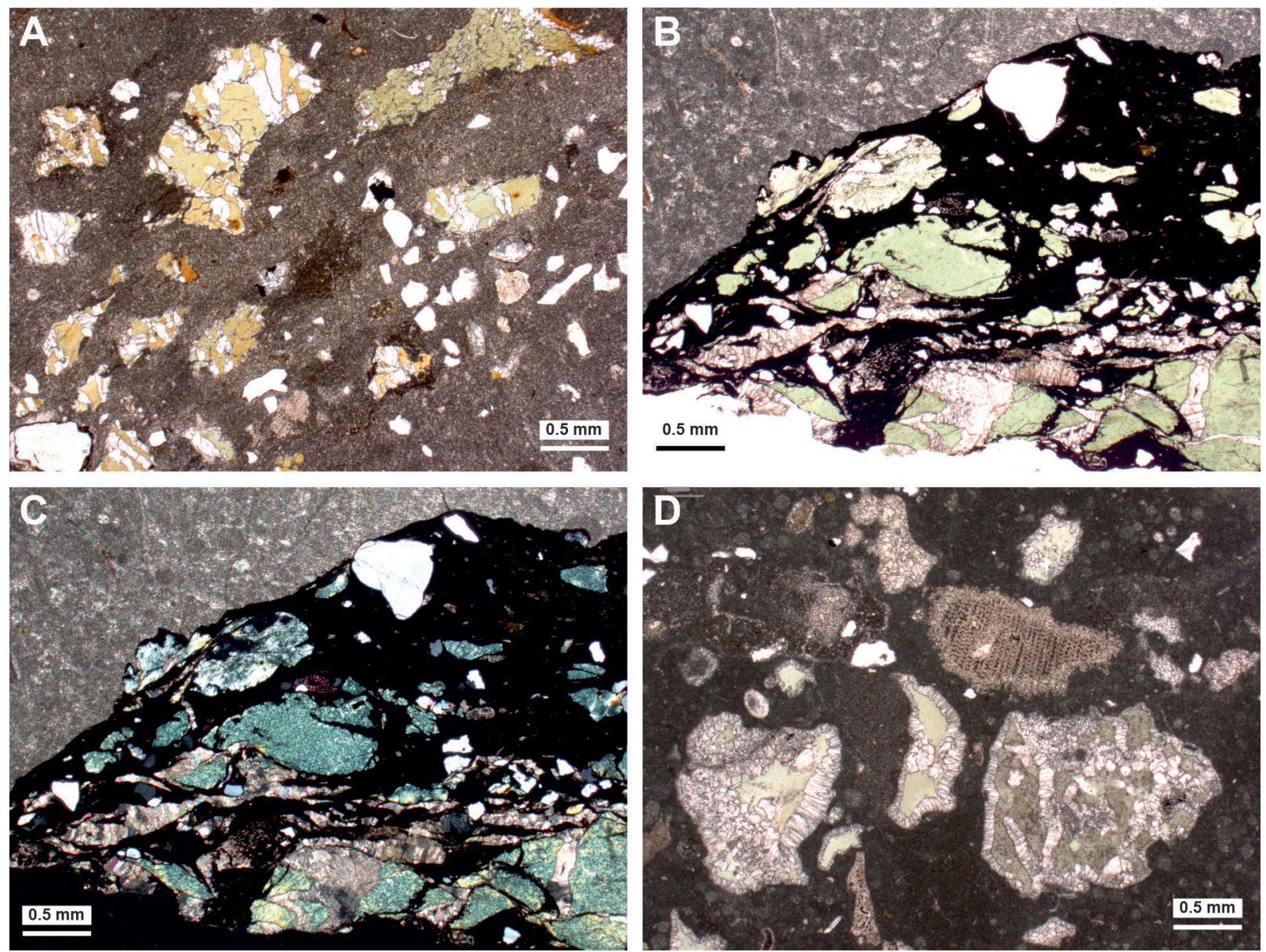
